Article

\title{
Geostatistical and Remote Sensing Studies to Identify High Metallogenic Potential Regions in the Kivi Area of Iran
}

\author{
Adel Shirazy ${ }^{1} \mathbb{D}$, Mansour Ziaii ${ }^{1}$, Ardeshir Hezarkhani ${ }^{2}$ and Timofey Timkin ${ }^{3, * \mathbb{D}}$ \\ 1 Faculty of Mining, Petroleum \& Geophysics Engineering, Shahrood University of Technology, \\ Shahrood 3619995161, Iran; Adel.shirazy@shahroodut.ac.ir (A.S.); mziaii@shahroodut.ac.ir (M.Z.) \\ 2 Mining Engineering Department, Amirkabir University of Technology (Tehran Polytechnic), \\ Tehran 1591634311, Iran; Ardehez@aut.ac.ir \\ 3 School of Earth Sciences \& Engineering, Tomsk Polytechnic University, 634050 Tomsk, Russia \\ * Correspondence: timkin@tpu.ru; Tel.: +7-3822606213
}

Received: 20 August 2020; Accepted: 29 September 2020; Published: 30 September 2020

\begin{abstract}
The Kivi area in the East Azerbaijan Province of Iran is one of the country's highest-potential regions for metal element exploration. The primary goal herein was to process the data obtained from geochemical, geostatistical, and remote sensing tools (in the form of stream sediment samples and satellite images) to identify metallic mineralization anomalies in the region. After correcting the raw stream sediment geochemical data, single-variable statistical processing was performed, and $\mathrm{Ti}$ and $\mathrm{Zn}$ were identified as the elements with the highest degree of contrast. The relationship among these elements was further investigated using correlation and hierarchical clustering analyses. Principal component analysis was then applied to determine the principal components related to these elements, which were subsequently plotted on a regional geological map. Elements related to $\mathrm{Ti}$ and $\mathrm{Zn}$ were identified using threshold limits of anomalous samples determined via linear discriminant analysis. Lithological units and alteration patterns were detected through remote sensing investigations on Landsat-8 images. Stream sediment geochemical and remote sensing survey results identified anomalous areas of $\mathrm{Ti}$ and $\mathrm{Zn}$ in the eastern part of the study region. Our results indicate that $\mathrm{Ti}$ and $\mathrm{Zn}$ are good pathfinder elements for further exploratory investigation in this area.
\end{abstract}

Keywords: geochemical exploration; geostatistics; stream sediment samples; exploratory remote sensing; principal component analysis; linear discriminant analysis

\section{Introduction}

Currently, geochemical exploration is deemed a critical means of generating a data layer in the mineral exploration process [1-8]. Many parameters are used in exploratory data analysis-including the full range of geochemical analysis products, the detection limits, sensitivity and accuracy of analyzers, the possibility of analyzing various geochemical variables and various data processing methods-with the goal of obtaining optimal results. Other tools relied upon by modern geochemists include software applications suitable for achieving exploration goals [9]. Once the enormous amount of information that has been entered into the exploration of geochemical data processing cycles has been digitized, experts can obtain solutions for determining high-potential and promising exploration regions [10].

The efficiency of the classic exploratory system and the current reliance on objective findings in the desert are not well-suited to exploration. Mineral exploration studies can make it easier to achieve exploration goals through a sequential process of applying statistical rules and geostatistical methods for determining the probability of mineral concentrations [11]. The Kivi area, located in the 
East Azerbaijan Province of Iran, has a high mineral potential of metal elements that can be better defined through geochemical investigation. Herein, the presence of the elements $\mathrm{Ti}, \mathrm{Zn}, \mathrm{Mn}, \mathrm{Cr}, \mathrm{Sr}, \mathrm{Mo}$, $\mathrm{Cu}, \mathrm{Ag}$, and $\mathrm{As}$ in the region was assessed using single-variable analysis and comparison with the concentration limits in stream sediments. By investigating the behavior of these elements in terms of their direct and relative relationships, several were identified as present in sufficient concentrations for potential exploitation. The principal components analysis (PCA) statistical method [12] was used to identify the lithology of the region and the mineralization marker as the primary and secondary components, respectively. To obtain more accurate results, a tree diagram of the hierarchical clustering of the elements was drawn using methods such as the squared Euclidean distance [13,14], reducing the set of elements related to mineralization in the region to $\mathrm{Ti}$ and $\mathrm{Zn}$. The statistical communities of these two elements were then separated based on a probability diagram, and the geochemical limits of each community were determined and analysed via linear discriminant analysis (LDA) $[15,16]$. Finally, satellite image processing methods were used to identify the alteration and lithological units [17] in the Kivi area and the results were compared with those of other statistical studies.

\section{Geological Setting of the Kivi Area}

Figure 1 shows a geological map of Kivi (scale 1:100,000), including the Ardabil Province in the vicinity of the cities of Ardabil, Khalkhal and Mianeh. The study area is located in the northwestern portion of the 1:250,000 geological map of Anzali port and has the geographical coordinates $48^{\circ} 00^{\prime}$ to $48^{\circ} 30^{\prime}$ E longitude and $37^{\circ} 30^{\prime}$ to $38^{\circ} 00^{\prime} \mathrm{N}$ latitude.

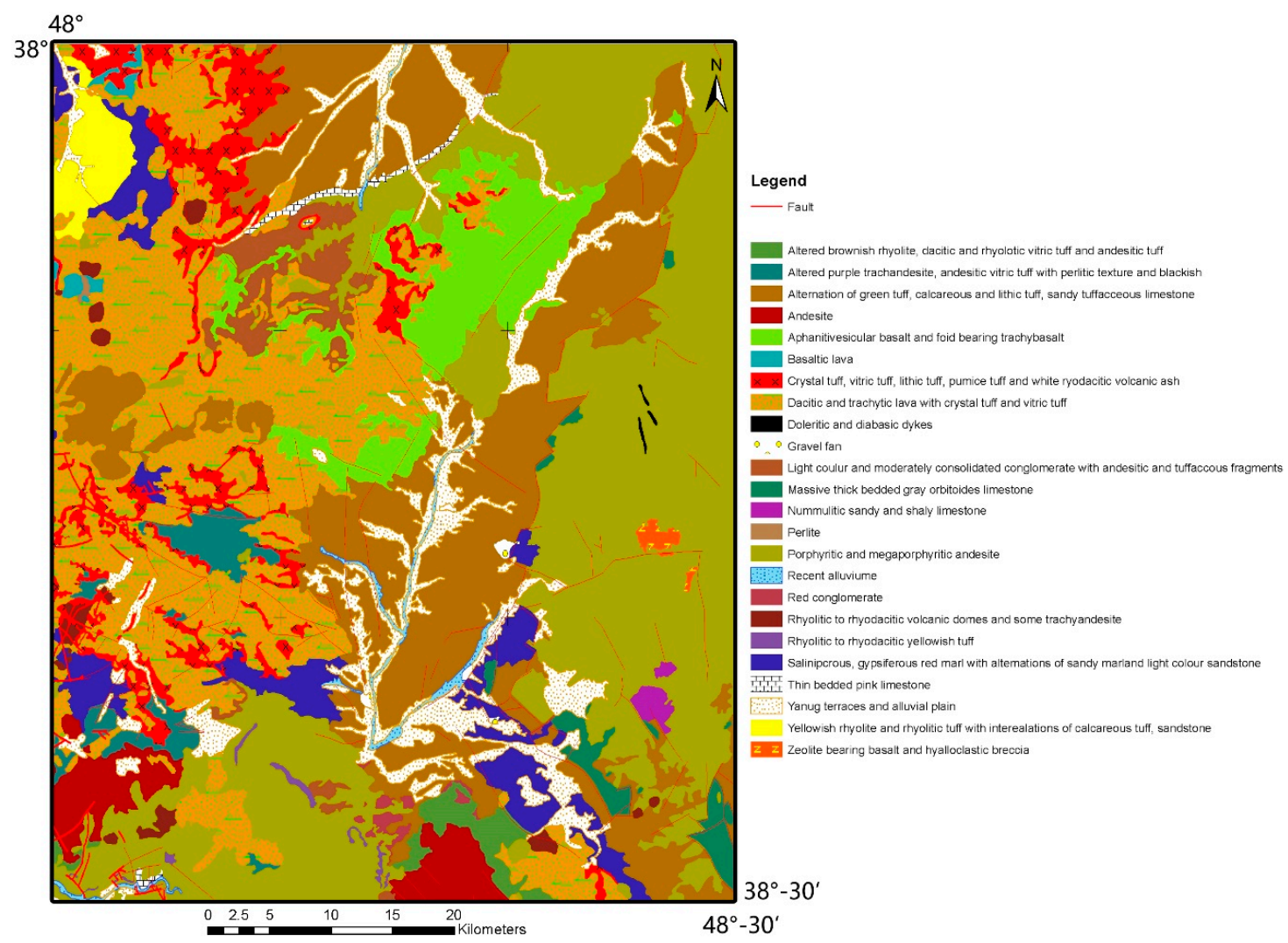

Figure 1. Simplified geological map of the Kivi area with streams. (Left: by Time, Right: by lithology).

The mountain ranges in this region trend mostly north-south and have a very harsh morphology, which is clearly visible in some areas, particularly in the drainages. The region includes Eocene and young volcanic rocks in the northwest, and along the Ardabil-Kivi road there are outcrops of Neogene loose marl sediments, flat ground, and hill-like marshes. In general, there are two main mountain 
ranges in this area: in the eastern part of the region, the highest elevation exceeds $2600 \mathrm{~m}$, and in the western part, the highest elevation is approximately $2500 \mathrm{~m}$.

The Kivi area comprises three sedimentary, igneous and metamorphic units. The oldest existing sedimentary unit comprises pre-Cretaceous rocks, whereas the youngest comprises Quaternary sediments. The geological characteristics of the rock units are as follows.

\subsection{Pre-Cretaceous Rocks}

These are found in the western part of Haji Yousef Village along the Sangabad Road, with outcrops of metamorphic rocks including sericite schist and andalusite micaschiste.

\subsection{Upper Cretaceous}

Cretaceous limestone outcrops are found only in the southeastern part of the study area and are more spread out towards the east. This unit is a massive-to-thick layered silica limestone, interlayered with lime, calcareous and pyrite shales. It is grey in colour.

\subsection{Eocene}

The Eocene deposit in the region is a sedimentary and igneous unit that covers majority of the area and includes conglomerate, green tuffs, tuffaceous sandstone, lithic tuff, sand and tuff limestone, andesitic lava, andesitic basalt, and basalt and rhyolitic and rhyodacitic yellowish tuffs.

\subsection{Oligocene}

Following the vast Eocene volcanic activity with a probable gap, Oligocene rhyolite, and an andesitic eruption "related to pyrenean orogeny" activities, were continued with marl and sandstone sedimentation.

\subsection{Miocene}

The Miocene unit includes lahar with trachytic and dacitic fragments, perlite, dacitic, and trachytic lava with crystal tuff and vitric tuff and ignimbrite in the west of the Kivi region. In addition, there are dacite-trachyte with cherty bands, pumice tuff, lithic tuff, and white rhyodacitic volcanic ash in the northwest. Altered purple trachyandesite and andesitic vitric tuff with perthitic texture are located in the southwestern part of the region.

\subsection{Quaternary}

The youngest volcanic rocks in the study area are black basalts with vesicular texture that horizontally cover all older stones. Travertine outcrops with white, lemon, and red coloring occur in the mid-east of the region. This unit comprises stream sediments such as rubble and sand. The igneous rocks include dacitic, middle, and basic combinations. There are Gabbro outcrops in the eastern and northern parts of the study area. All intrusive masses cut Eocene volcanic rocks, possibly as a result of a Pyrenean (Eocene-Oligocene) orogenous phase.

\section{Methodology and Materials}

\subsection{Exploration Geochemistry}

A stream sediment sampling method in which 714 samples of stream sediments were collected from the Kivi area and analysed for the presence of 63 elements using the inductively coupled plasma-mass-spectrometry (ICP-MS) method (Table 1) was applied. Figure 2 shows the locations from which the samples were collected. 
Table 1. Element determined on the stream sediment samples $(N=714)$.

\begin{tabular}{cccccccccccccc}
\hline \multicolumn{11}{c}{ Elements } \\
\hline $\mathrm{Ag}$ & $\mathrm{Al}$ & $\mathrm{As}$ & $\mathrm{Au}$ & $\mathrm{Ba}$ & $\mathrm{B}$ & $\mathrm{Be}$ & $\mathrm{Bi}$ & $\mathrm{Br}$ & $\mathrm{Ca}$ & $\mathrm{Cd}$ & $\mathrm{Ce}$ & $\mathrm{Co}$ & $\mathrm{Cr}$ \\
$\mathrm{Cs}$ & $\mathrm{Cu}$ & $\mathrm{Eu}$ & $\mathrm{F}$ & $\mathrm{Fe}$ & $\mathrm{Ga}$ & $\mathrm{Ge}$ & $\mathrm{Hf}$ & $\mathrm{Hg}$ & $\mathrm{In}$ & $\mathrm{Ir}$ & $\mathrm{K}$ & $\mathrm{La}$ & $\mathrm{Li}$ \\
$\mathrm{Mg}$ & $\mathrm{Mn}$ & $\mathrm{Mo}$ & $\mathrm{Na}$ & $\mathrm{Nb}$ & $\mathrm{Nd}$ & $\mathrm{Ni}$ & $\mathrm{Os}$ & $\mathrm{P}$ & $\mathrm{Pb}$ & $\mathrm{Pd}$ & $\mathrm{Pr}$ & $\mathrm{Pt}$ & $\mathrm{Rb}$ \\
$\mathrm{Re}$ & $\mathrm{Ru}$ & $\mathrm{S}$ & $\mathrm{Sb}$ & $\mathrm{Sc}$ & $\mathrm{Se}$ & $\mathrm{Si}$ & $\mathrm{Sn}$ & $\mathrm{Sr}$ & $\mathrm{Ta}$ & $\mathrm{Te}$ & $\mathrm{Th}$ & $\mathrm{Ti}$ & $\mathrm{Tl}$ \\
$\mathrm{U}$ & $\mathrm{V}$ & $\mathrm{W}$ & $\mathrm{Y}$ & $\mathrm{Yb}$ & $\mathrm{Zn}$ & $\mathrm{Zr}$ & & & & & & & \\
\hline
\end{tabular}

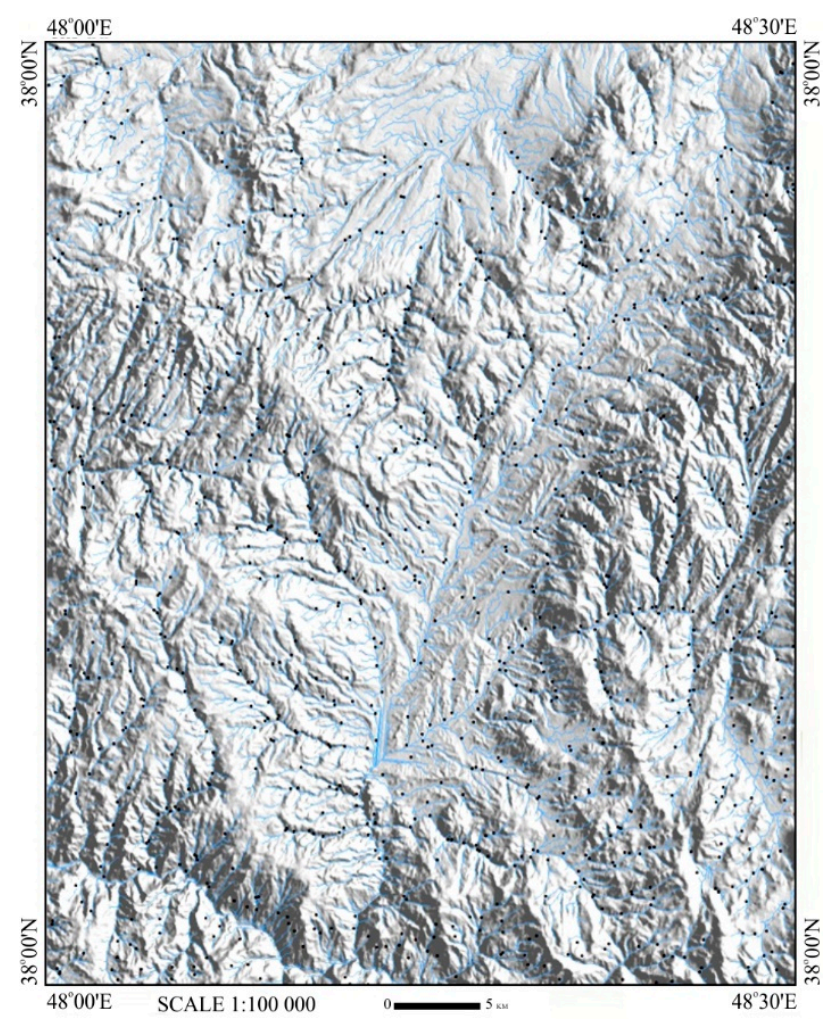

Figure 2. Topographical map showing the location of stream sediment samples in the Kivi area.

\subsubsection{Raw Data Preparation Methods}

Before using raw data, censored and outlier data must be identified and replaced. Such data cause problems in the application of statistical methods, which require a complete set of non-censored data. In some cases, such as the separation of anomalies from the background and relative measurement, the presence of censored data produces inappropriate evaluation results. If the censored data are identified and replaced, the amount of background and the intensity of anomalies can be calculated with high accuracy [18].

Outlier data have the same effect as censored data in terms of generating errors from geochemical data. Outlier data, which are data points that significantly deviate from other observed data $[19,20]$, typically have two sources: sampling error and errors in laboratory measurement and analysis [21]. Outlier data can cause serious problems in statistical investigation and the future decisions based on its results [22].

Several methods can be used to detect and replace censored and outlier data. Herein, a simple method was used to replace censored data in which values below the analyzer detection limit were replaced by $3 / 4$ of the recorded values. However, this method has a fundamental problem in that it is not affected by the statistical parameters of the data community and is merely a function of the sensitivity of the measurement method $[18,23]$. 
The Doerffel method was used to identify and replace outlier data [22]. Doerffel developed a graph for determining the threshold of outlier data values at two levels of accuracy: 5\% and 1\% (see Figure 4) [24,25].

To perform the Doerffel test, the averages $(\bar{x})$ and standard deviations of the data points were calculated regardless of the maximum data value. The largest data value $\left(x_{A}\right)$ was considered to be outside of the range if the following equation was satisfied:

$$
x_{A} \geq \bar{x}+s \cdot g
$$

where " $g$ " is the threshold limit for outlier values, which can be calculated using the graph shown in Figure 3.

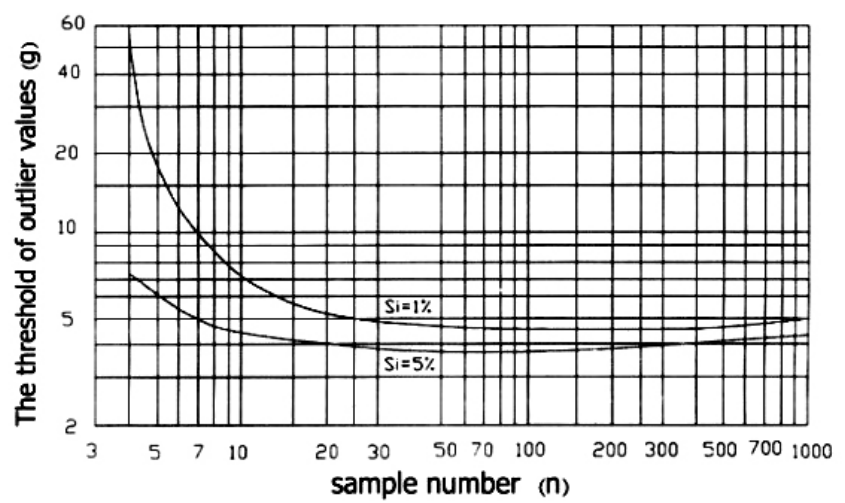

Figure 3. The threshold of outlier values $(g)$ as a function of the sample number $(n)$ and the level of accuracy.

\subsubsection{Correlation Investigations of Raw Data}

By applying correlation analysis to the raw data, the relationship between each set of two elements could be calculated. Using these results, the relationship between the mineralization and mobility of different elements can be identified [25]. Correlation analysis is useful in predicting the behaviour of elements in a region [26], and a behavioral analysis of different elements can be used to determine the relationship between mineralization and geochemical halos $[27,28]$.

\subsubsection{Hierarchical Clustering Analysis Method (HCA)}

The hierarchical clustering analysis (HCA) method was used to divide elements into clusters within which related elements could be grouped. HCA can be applied using two different clustering strategies — the agglomerative and divisive methods—which are shown in Figure 4 [29].

\section{Hierarchical Clustering}

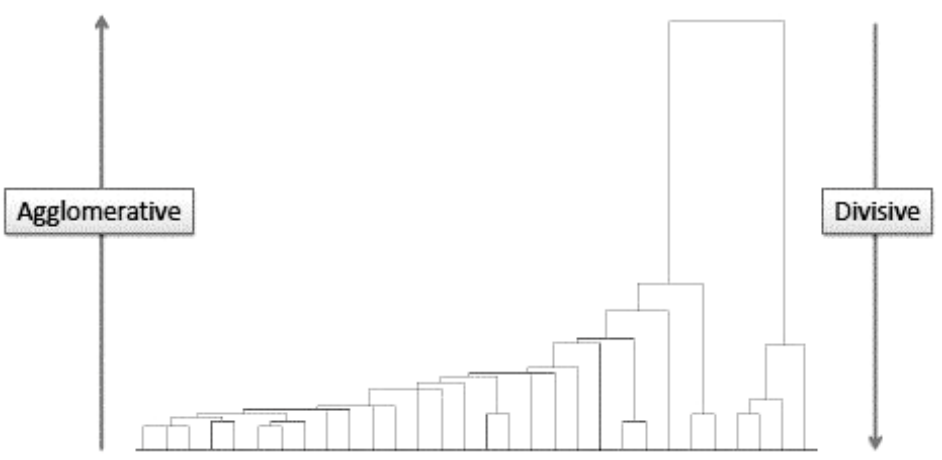

Figure 4. Hierarchical clustering strategies. 


\subsubsection{Principal Components Analysis (PCA)}

The principal components method (PCA) method is used to reduce the size of a dataset. By applying this method, the overall set of data can be replaced by data that are most highly correlated with each other [30,31]. The PCA method is based on the calculation of eigenvalues and eigenvectors to reduce the dimensionality of the dataset [32]. The new data generated by PCA will therefore be independent of each other [18]. To obtain the eigenvalues and eigenvectors, the bands correlation matrix must be calculated first [33].

\subsubsection{Linear Discriminant Analysis (LDA)}

LDA is a community separation technique [34] based on the number of categories that include interdependent variables [35]. Figure 5 presents the steps of LDA [36,37].

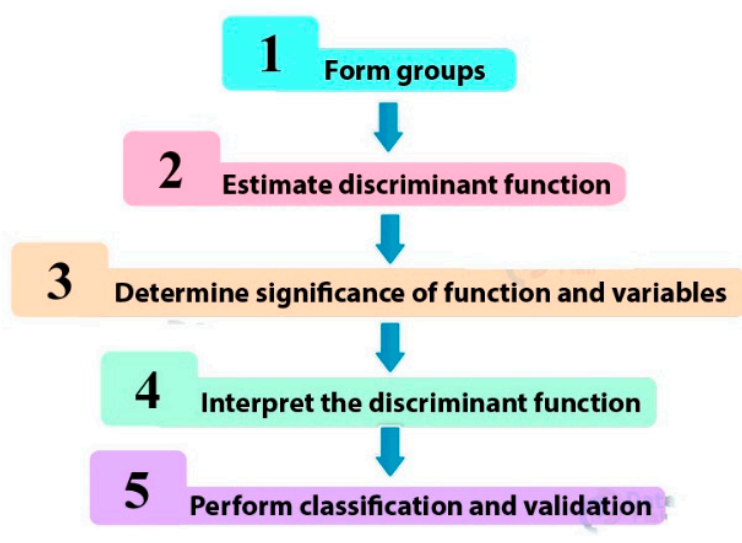

Figure 5. Steps in discriminant analysis.

Figure 6 shows the application of linear classification boundaries when a dataset including two variable groups is modeled using LDA [28].

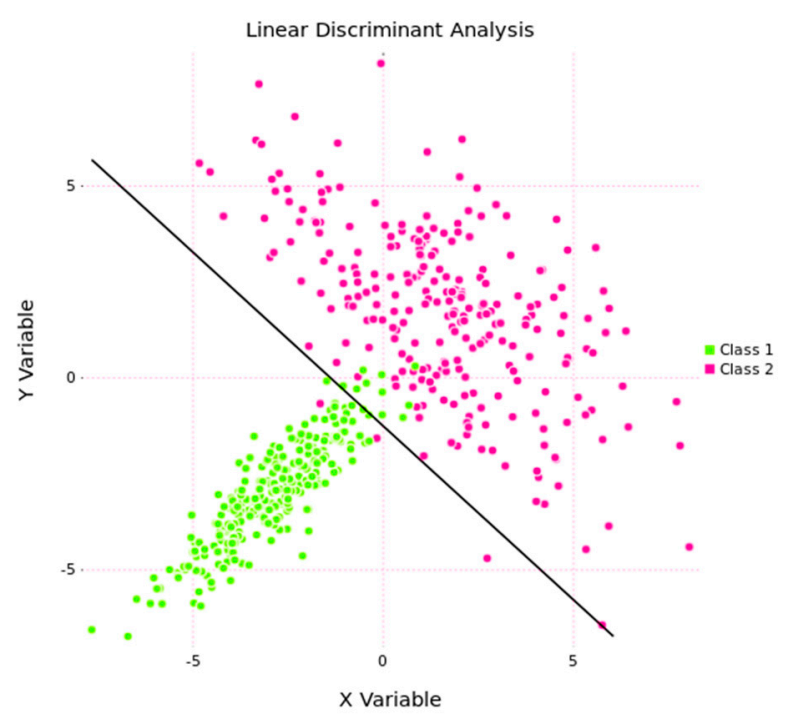

Figure 6. Schematic image of the separation of two communities by linear discriminant analysis (LDA) method.

\subsection{Exploratory Remote Sensing}

Herein, remote sensing was performed using the Landsat 8 satellite data for the Kivi region. Methods used for remote sensing on raw corrected satellite data include band combinations and 
multiplications, band ratios and developed selective PCA (DSPCA), which is applied to the shortwave infrared (SWIR) and near infrared (NIR) spectral bands of Landsat-8 [38,39].

Lithological units can be separated and high-potential mineral areas can be identified using advanced remote sensing (RS) methods in the SWIR and NIR spectral bands of the satellite [40-43]. The accuracy of the images used in this study ranged between 15 and $100 \mathrm{~m}$ [44].

\section{Remote Sensing Data}

A cloud-free remotely sensed dataset from the Landsat-8 sensor (October 2017) covering the Kivi area was obtained through the United States Geological Survey and its metadata were used to transform recorded digital number values to radiance values [45]. The internal average relative reflectance (IARR) [46] was used as an atmospheric correction technique; to normalize images to a scene average for obtaining reflectance from the radiance data: the IARR calibration was applied [47] and the images were then resized to the research area.

\section{Results and Discussion}

\subsection{Exploratory Geochemistry}

\subsubsection{Censored and Outlier Data}

Given the large quantity of censored data in some of the elements, censored elements were, to the greatest extent possible, replaced with values obtained using the Doerffel method, whereas elements with very high values were removed. Table 2 lists the remaining elements following the initial refinement.

Table 2. Analyzed elements after initial refinement.

\begin{tabular}{|c|c|c|c|c|c|c|c|c|c|}
\hline \multicolumn{10}{|c|}{ Elements } \\
\hline $\mathrm{Ag}$ & As & $\mathrm{Au}$ & $\mathrm{Ba}$ & $\mathrm{Be}$ & $\mathrm{Co}$ & $\mathrm{Cr}$ & $\mathrm{Cu}$ & $\mathrm{Mn}$ & Mo \\
\hline $\mathrm{Ni}$ & $\mathrm{Pb}$ & $\mathrm{Sb}$ & $\mathrm{Se}$ & Sn & $\mathrm{Sr}$ & $\mathrm{Ti}$ & $\mathrm{W}$ & $\mathrm{Zn}$ & \\
\hline
\end{tabular}

\subsubsection{Single-Variable Initial Analysis}

After analyzing the data in single-variable form, as listed in Table 3, the most important elements for the study were selected according to a histogram and probability diagram of the overall dataset.

In cases of mineralization or contamination of samples through anthropogenic activities in the region, the mean values did not correspond to the median values, which deviated to the left or right of the mean. In this condition, there was no symmetry in the histogram. In the probability diagram, the data did not lie along a straight line. Consequently, the important elements were separated from other elements owing to their high values relative to the background as well as the skewness, Kurtosis, and asymmetry of the histogram and the non-linearity of the probability graph. Based on the results listed in Table 3, which presents a statistical analysis of the elements and the anomalous limits of each element in the stream sediments, eight important elements were selected and arranged in order of priority. The elements suspected of being anomalous to the area are also listed in the Table 3. Ti and $\mathrm{Zn}$ were identified as the most important elements in the region based on the statistical parameters and anomalous limits of the stream sediments. Probability charts and non-logarithmic histograms of Ti and $\mathrm{Zn}$ are plotted in Figures 7 and 8, respectively. 
Table 3. Single-variable statistics parameters and anomalous limits for elements in drainage sediments.

\begin{tabular}{|c|c|c|c|c|c|c|c|c|c|c|c|c|}
\hline \multirow{2}{*}{ Elements } & Mean & Median & Mode & Min & Max & \multirow{2}{*}{$\begin{array}{l}\text { Varance } \\
(\mathrm{ppm})^{2}\end{array}$} & \multirow{2}{*}{ Skewness } & \multirow{2}{*}{ Kurtosis } & \multirow{2}{*}{$\begin{array}{c}\text { Standard } \\
\text { Deviation (ppm) }\end{array}$} & \multirow{2}{*}{ CV } & \multirow{2}{*}{$\begin{array}{l}\text { Anomalous } \\
\text { Limit (ppm) }\end{array}$} & \multirow{2}{*}{$\begin{array}{l}\text { Anomal } \\
\text { Priority }\end{array}$} \\
\hline & & & ppm & & & & & & & & & \\
\hline $\mathrm{Ag}$ & 0 & 0.15 & 0.13 & 0.03 & 4.80 & 0.079 & 10.84 & 147.2 & 0.2803 & 140.17 & 0.1 & 7 \\
\hline As & 15 & 10.85 & 4.9 & 0.50 & 175 & 250.78 & 4.35 & 26.92 & 15.84 & 102.83 & 1 to 50 & 8 \\
\hline $\mathrm{Au}$ & 0 & 0 & 0 & 0.00 & 0.02 & 0.000 & 3.34 & 18.90 & 0.0018 & 78.87 & - & - \\
\hline $\mathrm{Ba}$ & 657 & 661 & 628 & 169 & 1480 & $42,519.1$ & 0.195 & -0.005 & 206.21 & 31.41 & 100 to 3000 & Suspicious \\
\hline $\mathrm{Be}$ & 2 & 1.9 & 2.00 & 1 & 14 & 1.49 & 3.97 & 21.84 & 1.22 & 55.52 & 6 & - \\
\hline Co & 18 & 16.65 & 17 & 3.5 & 62.2 & 53.47 & 1.20 & 2.55 & 7.31 & 40.62 & 1 to 40 & Suspicious \\
\hline $\mathrm{Cr}$ & 73 & 48 & 40 & 11 & 1100 & 7155.69 & 5.18 & 41.83 & 84.59 & 116.52 & 5 to 1000 & 3 \\
\hline $\mathrm{Cu}$ & 80 & 70 & 112 & 13 & 222 & 1756.87 & 0.94 & 0.32 & 41.92 & 52.39 & 2 to 100 & 5 \\
\hline Mn & 989 & 956 & 1000 & 449 & 3160 & $52,997.3$ & 2.27 & 13.03 & 230.21 & 23.28 & 850 & 4 \\
\hline Mo & 2 & 1.90 & 1.5 & 0.1 & 38.6 & 3.48 & 10.77 & 202.7 & 1.86 & 83.99 & 2 & 6 \\
\hline $\mathrm{Ni}$ & 35 & 27 & 21 & 9 & 210 & 751.77 & 3.2 & 11.81 & 27.42 & 79.48 & 5 to 500 & Suspicious \\
\hline $\mathrm{Pb}$ & 16 & 15.4 & 15.1 & 5.9 & 56.2 & 20.46 & 2.36 & 14.54 & 4.52 & 28.63 & 2 to 200 & $1-$ \\
\hline $\mathrm{Sb}$ & 2 & 1.3 & 0.8 & 0.2 & 25.3 & 5.68 & 3.67 & 19.99 & 2.38 & 113.53 & 5 & - \\
\hline Se & 1 & 0.7 & 0.7 & 0.2 & 1.8 & 0.07 & 0.41 & 0.3 & 0.26 & 38.45 & - & - \\
\hline Sn & 2 & 1.5 & 1.4 & 0.8 & 8.2 & 0.55 & 2.99 & 12.83 & 0.74 & 41.35 & 10 & - \\
\hline $\mathrm{Sr}$ & 501 & 490.5 & 464 & 70 & 1030 & $28,067.92$ & 0.17 & 0.061 & 167.53 & 33.44 & 50 to 1000 & 4 \\
\hline $\mathrm{Ti}$ & 5683 & 5440 & 5580 & 1940 & 21,700 & $2,938,249$ & 2.60 & 16.79 & 1714.13 & 30.16 & 5000 & 1 \\
\hline W & 3 & 2.2 & 2.1 & 0.8 & 9.6 & 1.59 & 2.204 & 6.59 & 1.26 & 48.55 & - & - \\
\hline $\mathrm{Zn}$ & 183.8 & 200.4 & 118 & 102.3 & 468 & 10.43 & 6.99 & 8.66 & 7.00 & 33.95 & 10 to 300 & 2 \\
\hline
\end{tabular}



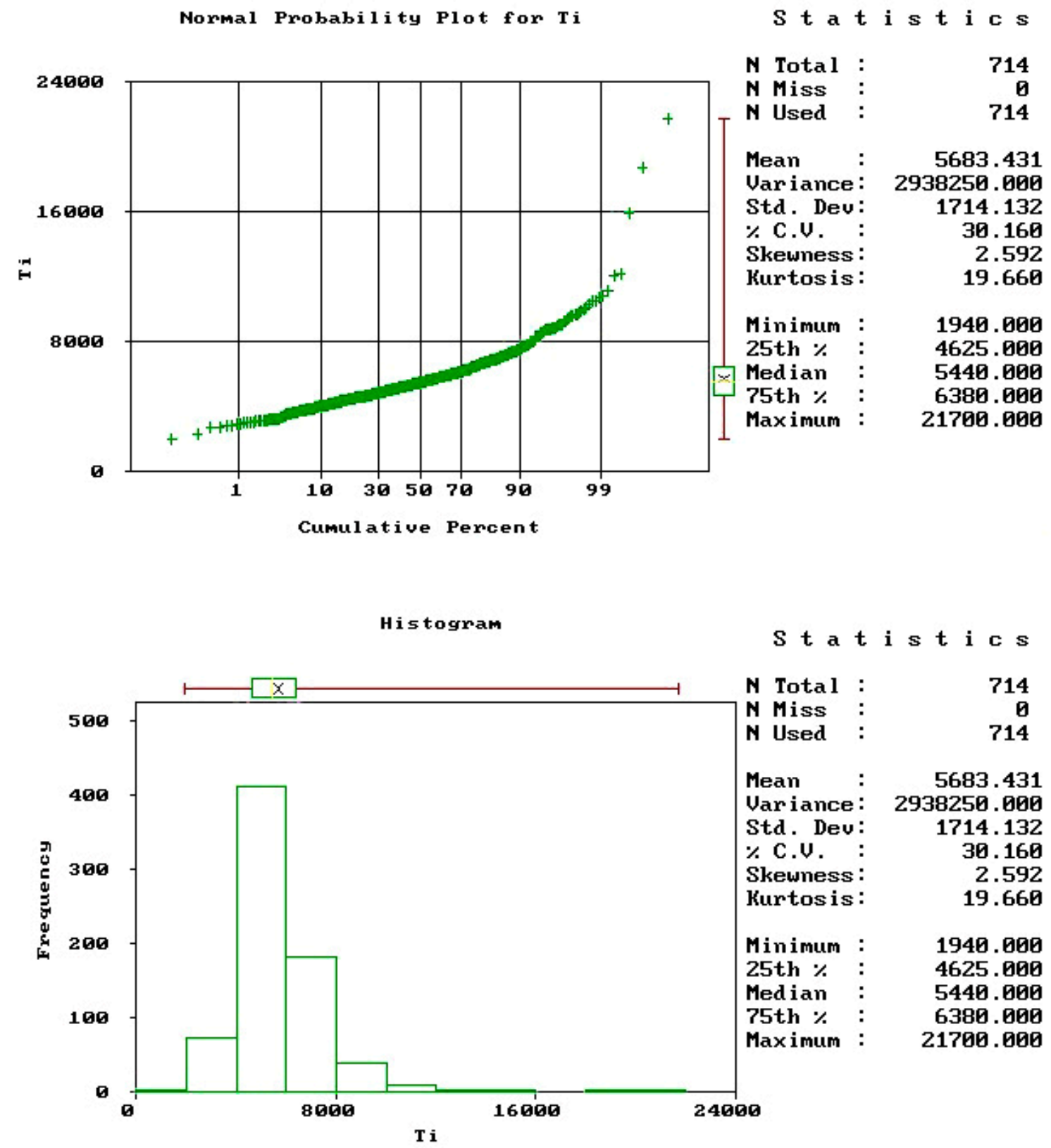

Figure 7. Probability diagram and in non-logarithmic histogram for Ti element. 
Normal Probability Plot for Zn

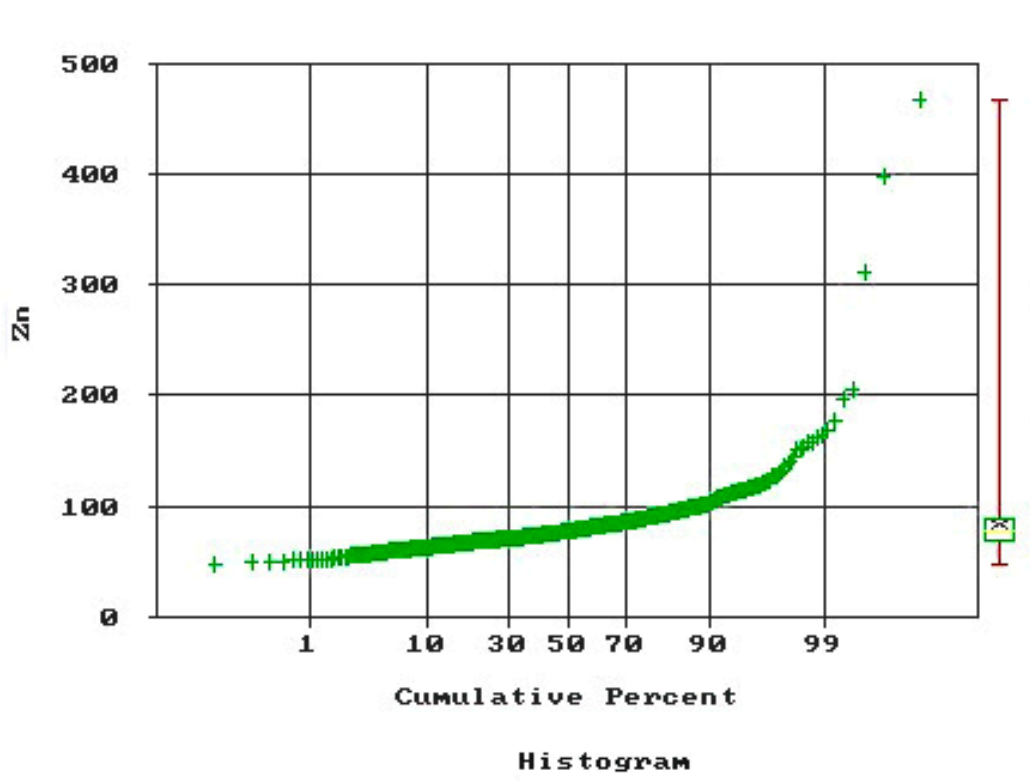

$s t a t i s t i c s$

N Total:

N Miss : 714

N Used : 714

Mean

82.420

Variance:

784.434

Std. Dev: 28.008

\% C.U. : $\quad 33.982$

Skewness: $\quad 6.979$

Kurtosis: $\quad \mathbf{8 1 . 1 0 6}$

Minimum : $\quad 47.300$

25 th $\%:$ : 69.500

Median : $\quad 77.460$

75 th $\%:$ : 88.450

Maximum : $\quad 468.000$

$S t a t i s t i c s$

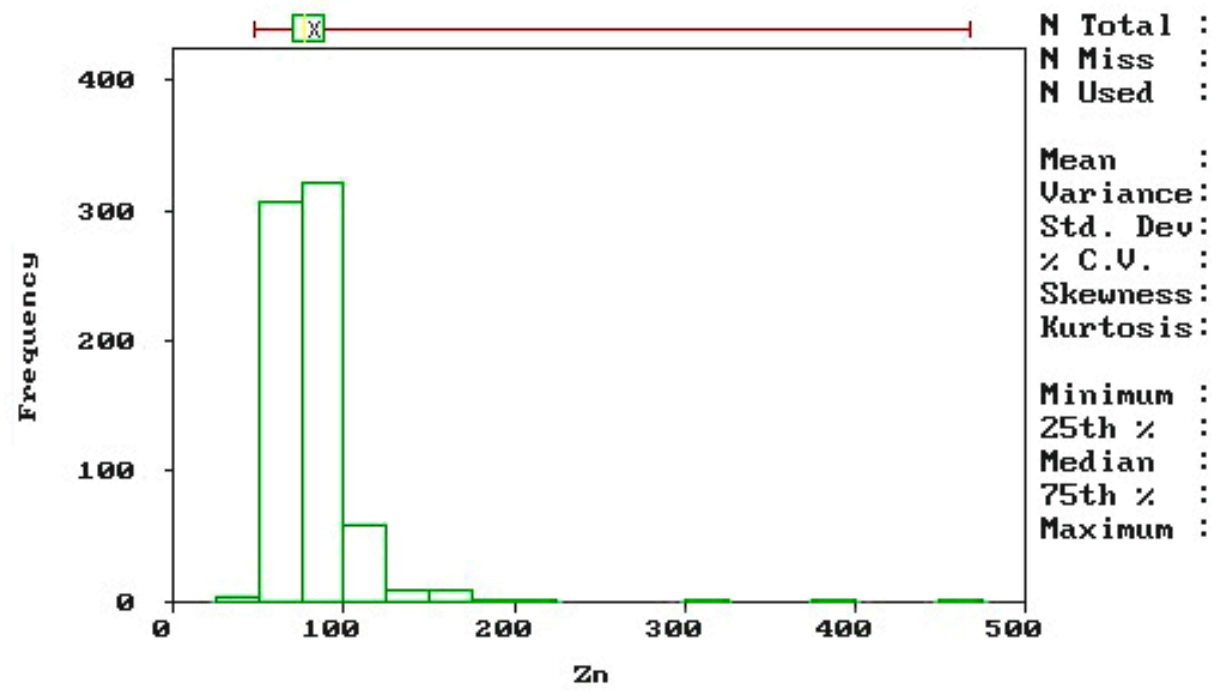

Figure 8. Probability diagram and in non-logarithmic histogram for Zn element.

\subsubsection{Correlation Coefficients and Hierarchical Clustering}

A lack of dependence between variables is the main criterion in single-variable and related statistical studies. However, in practice, such independence is not found in nature because various factors, such as genetics, effectively dominate the relationship and dependence between variables. Thus, the value of dependence between elements can be numerically expressed in terms of the correlation or geochemical correlation coefficient. To determine the relationship between the elements in the stream sediment samples, a correlation coefficient matrix between the elements was developed (Table 4). 
Table 4. Correlation coefficients of the studied elements.

\begin{tabular}{|c|c|c|c|c|c|c|c|c|c|c|c|c|c|c|c|c|c|c|c|}
\hline Elements & Ag & As & $\mathrm{Au}$ & Ba & Be & Co & $\mathrm{Cr}$ & $\mathrm{Cu}$ & Mn & Mo & $\mathrm{Ni}$ & $\mathrm{Pb}$ & $\mathrm{Sb}$ & Se & Sn & $\mathrm{Sr}$ & $\mathrm{Ti}$ & W & $\mathrm{Zn}$ \\
\hline $\mathrm{Ag}$ & 1.000 & & & & & & & & & & & & & & & & & & \\
\hline As & 0.128 & 1.000 & & & & & & & & & & & & & & & & & \\
\hline $\mathrm{Au}$ & 0.020 & 0.09 & 1.000 & & & & & & & & & & & & & & & & \\
\hline $\mathrm{Ba}$ & 0.085 & 0.277 & -0.091 & 1.000 & & & & & & & & & & & & & & & \\
\hline $\mathrm{Be}$ & 0.128 & 0.182 & 0.1 & 0.21 & 1.000 & & & & & & & & & & & & & & \\
\hline Co & -0.19 & -0.128 & -0.035 & -0.271 & -0.646 & 1.000 & & & & & & & & & & & & & \\
\hline $\mathrm{Cr}$ & -0.089 & -0.064 & -0.073 & -0.327 & -0.563 & 0.678 & 1.000 & & & & & & & & & & & & \\
\hline $\mathrm{Cu}$ & 0.171 & 0.048 & 0.019 & 0.516 & -0.004 & 0.063 & -0.15 & 1.000 & & & & & & & & & & & \\
\hline $\mathrm{Mn}$ & -0.112 & -0.061 & 0.015 & -0.092 & -0.097 & 0.526 & 0.387 & -0.045 & 1.000 & & & & & & & & & & \\
\hline Mo & 0.295 & 0.241 & 0.021 & 0.081 & 0.523 & -0.381 & -0.194 & 0.001 & -0.046 & 1.000 & & & & & & & & & \\
\hline $\mathrm{Ni}$ & -0.083 & -0.138 & -0.013 & -0.442 & -0.463 & 0.581 & 0.822 & -0.261 & 0.319 & -0.248 & 1.000 & & & & & & & & \\
\hline $\mathrm{Pb}$ & 0.248 & 0.307 & 0.08 & 0.345 & 0.689 & -0.518 & -0.359 & 0.011 & -0.082 & 0.506 & -0.308 & 1.000 & & & & & & & \\
\hline $\mathrm{Sb}$ & 0.217 & 0.655 & 0.070 & 0.015 & 0.058 & -0.159 & 0.068 & -0.232 & -0.11 & 0.283 & 0.018 & 0.18 & 1.000 & & & & & & \\
\hline Se & 0.294 & -0.077 & 0.028 & -0.256 & 0.033 & 0.007 & 0.097 & -0.161 & 0.1 & 0.213 & 0.133 & 0.034 & 0.048 & 1.000 & & & & & \\
\hline Sn & 0.256 & 0.226 & 0.068 & 0.003 & 0.64 & -0.375 & -0.169 & -0.188 & 0.010 & 0.555 & -0.181 & 0.632 & 0.19 & 0.19 & 1.000 & & & & \\
\hline $\mathrm{Sr}$ & -0.146 & -0.242 & -0.088 & 0.403 & -0.236 & 0.253 & 0.055 & 0.429 & 0.102 & -0.184 & 0.039 & -0.192 & -0.37 & -0.106 & -0.336 & 1.000 & & & \\
\hline $\mathrm{Ti}$ & -0.072 & 0.007 & -0.072 & -0.033 & -0.259 & 0.567 & 0.528 & -0.013 & 0.524 & -0.028 & 0.307 & -0.153 & 0.051 & -0.045 & 0.039 & 0.154 & 1.000 & & \\
\hline W & 0.183 & 0.409 & 0.109 & 0.189 & 0.697 & -0.569 & -0.382 & -0.105 & -0.176 & 0.526 & -0.35 & 0.631 & 0.361 & 0.078 & 0.638 & -0.263 & -0.229 & 1.000 & \\
\hline $\mathrm{Zn}$ & 0.065 & -0.076 & 0.042 & -0.252 & -0.050 & 0.42 & 0.411 & -0.053 & 0.534 & 0.058 & 0.318 & 0.064 & -0.033 & 0.186 & 0.207 & -0.033 & 0.618 & -0.161 & 1.000 \\
\hline
\end{tabular}

Spearman Coloration method. 
Based on the determined correlations, clustering was performed using the squared Euclidean distance after normalizing the data to values between zero and one, as shown in Figure 9, in which the hierarchical diagram clearly groups $\mathrm{Ti}$ and $\mathrm{Zn}$ into one cluster.

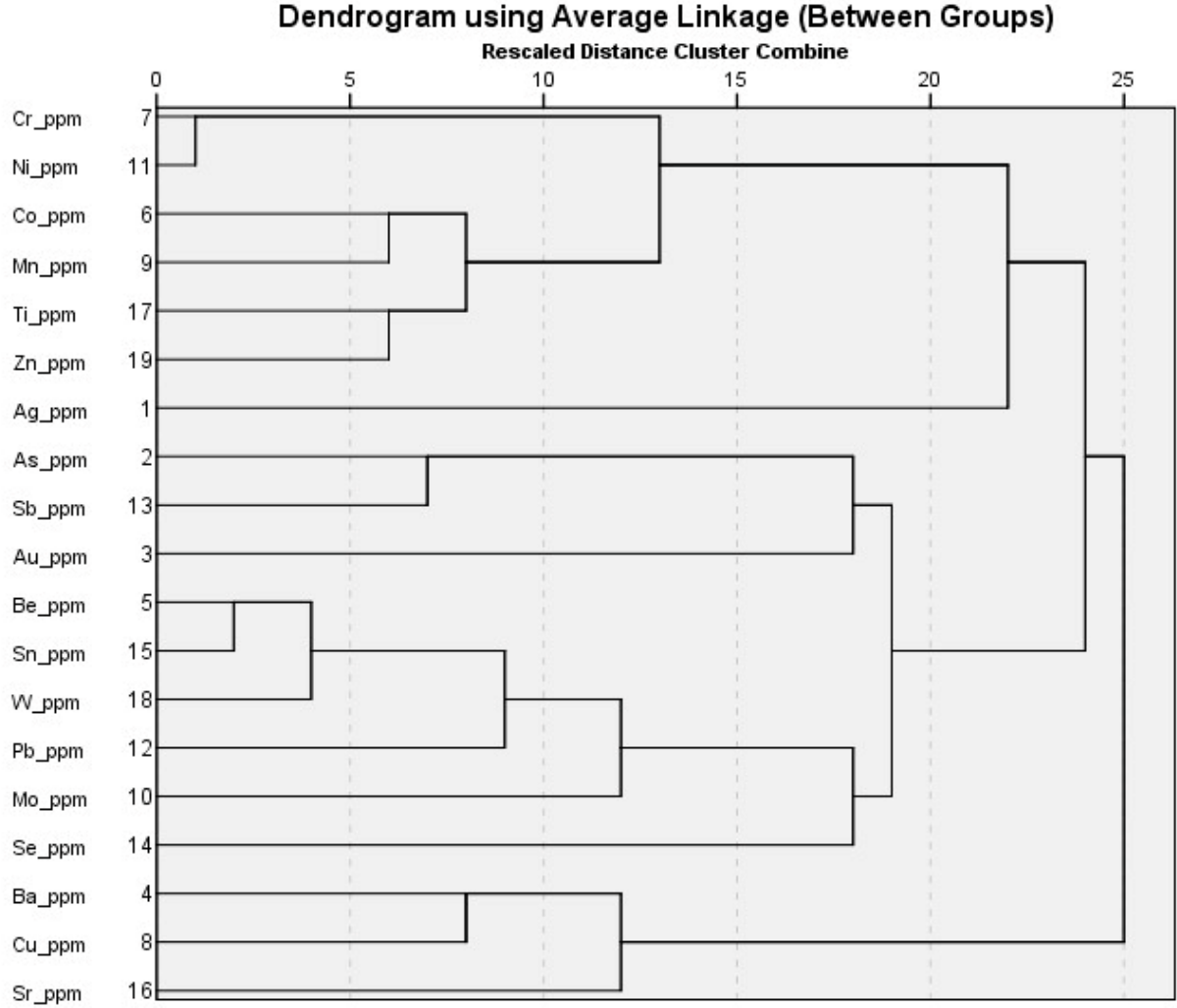

Figure 9. Hierarchical diagram of the elements in the Kivi area.

\subsubsection{Principal Components Analysis (PCA)}

As can be observed in Figure 10, six components were found to be appropriate. The values in red indicate the most important elements in each component. The first component describes the region's lithology whereas the second describes the mineralization (Table 5).

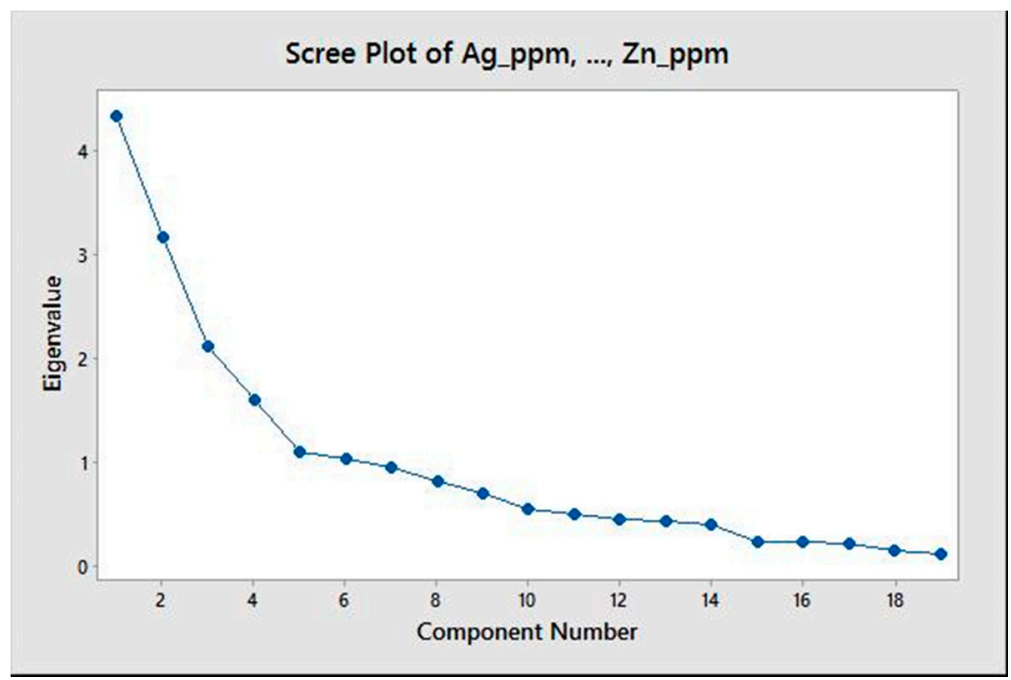

Figure 10. The scree plot of Principal Components Analysis (PCA) on elements. 
Table 5. Principal Components and their eigen values.

\begin{tabular}{ccccccc}
\hline \multirow{2}{*}{ Elements } & \multicolumn{7}{c}{ PC } \\
\cline { 2 - 7 } & $\mathbf{1}$ & $\mathbf{2}$ & $\mathbf{3}$ & $\mathbf{4}$ & $\mathbf{5}$ & $\mathbf{6}$ \\
\hline $\mathrm{Ag}$ & 0.011 & -0.061 & 0.134 & 0.174 & 0.097 & 0.827 \\
$\mathrm{As}$ & 0.084 & -0.006 & 0.084 & -0.014 & 0.825 & -0.029 \\
$\mathrm{Au}$ & -0.132 & 0.119 & -0.294 & -0.395 & 0.353 & 0.211 \\
$\mathrm{Ba}$ & -0.007 & -0.081 & 0.838 & -0.182 & 0.144 & -0.156 \\
$\mathrm{Be}$ & 0.803 & -0.110 & -0.301 & -0.178 & -0.147 & 0.011 \\
$\mathrm{Co}$ & -0.485 & 0.338 & -0.118 & 0.426 & -0.101 & -0.007 \\
$\mathrm{Cr}$ & -0.177 & 0.306 & -0.170 & 0.784 & 0.031 & 0.064 \\
$\mathrm{Cu}$ & -0.140 & -0.038 & 0.750 & -0.113 & -0.063 & 0.112 \\
$\mathrm{Mn}$ & -0.013 & 0.851 & -0.026 & 0.077 & -0.094 & -0.012 \\
$\mathrm{Mo}$ & 0.662 & 0.004 & 0.097 & 0.151 & 0.085 & 0.095 \\
$\mathrm{Ni}$ & -0.182 & 0.178 & -0.242 & 0.827 & -0.043 & 0.088 \\
$\mathrm{~Pb}$ & 0.688 & 0.161 & 0.244 & -0.169 & 0.374 & 0.005 \\
$\mathrm{Sb}$ & 0.147 & -0.003 & -0.091 & -0.017 & 0.842 & -0.010 \\
$\mathrm{Se}$ & 0.170 & 0.095 & -0.302 & -0.128 & -0.153 & 0.598 \\
$\mathrm{Sn}$ & 0.812 & 0.138 & -0.261 & -0.161 & -0.047 & 0.054 \\
$\mathrm{Sr}$ & -0.414 & 0.228 & 0.557 & -0.050 & -0.277 & -0.095 \\
$\mathrm{Ti}$ & -0.045 & 0.805 & 0.078 & 0.206 & 0.017 & -0.023 \\
$\mathrm{~W}$ & 0.766 & -0.082 & -0.200 & -0.203 & 0.224 & -0.004 \\
$\mathrm{Zn}$ & 0.221 & 0.826 & -0.067 & -0.003 & 0.152 & 0.071 \\
\hline
\end{tabular}

\subsubsection{Separating Communities on the Probability Chart}

The $\mathrm{Ti}$ and $\mathrm{Zn}$ communities were separated using a probability diagram to determine the boundaries of the geochemical threshold. The breakpoints of the probability chart, which represent changes in trend, were considered community boundaries [26]. Probability charts of Ti and $\mathrm{Zn}$ are shown in Figures 11 and 12, respectively, and anomalous values for the two elements are listed in Table 6.

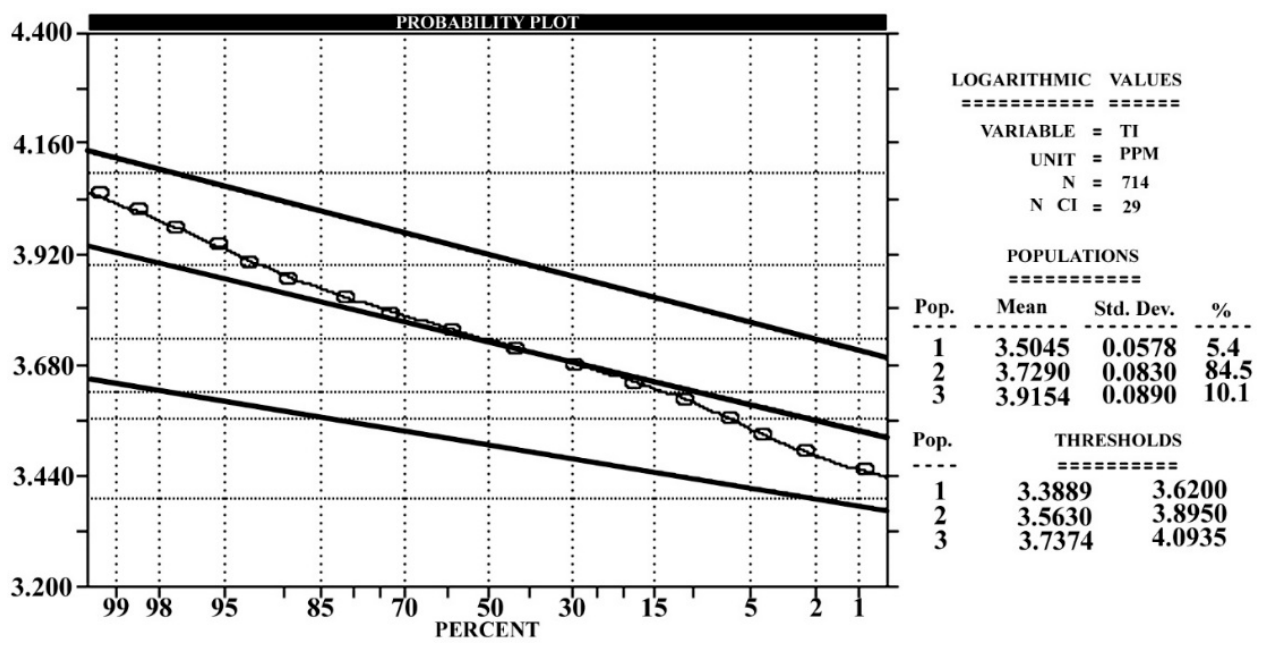

Figure 11. Separation of titanium element communities on the probability diagram. 


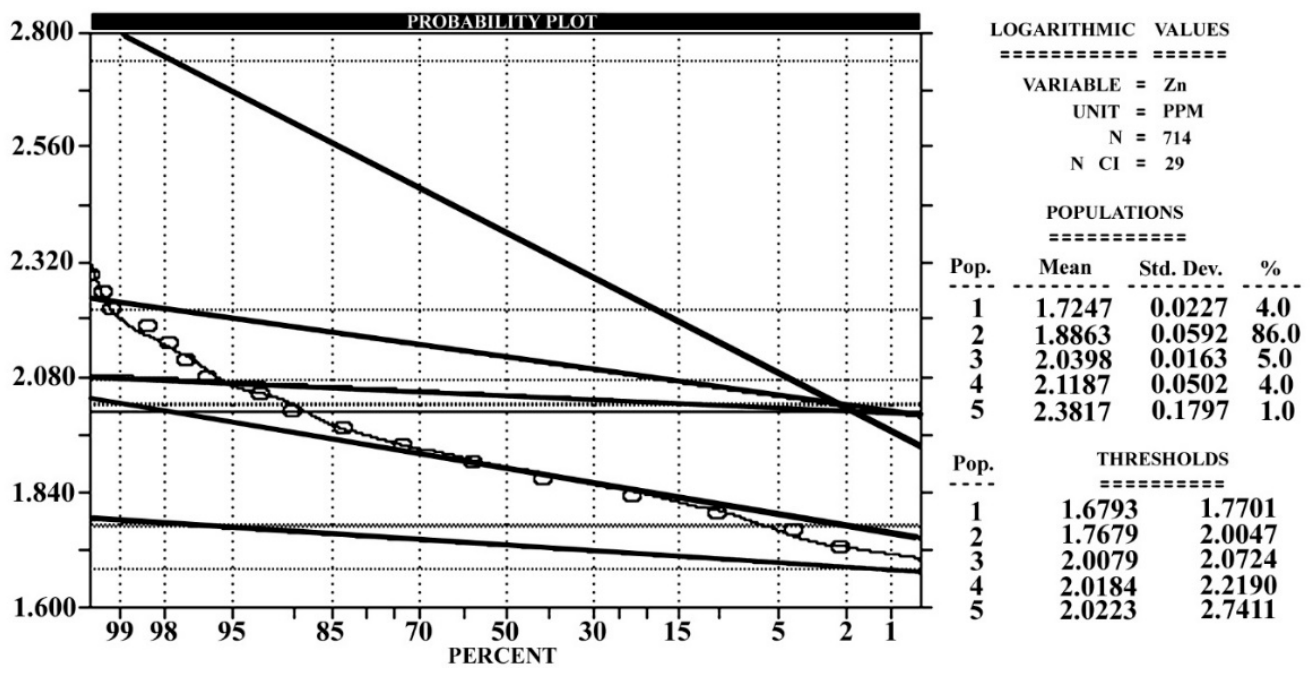

Figure 12. Separation of zinc element communities on the probability diagram.

Table 6. Anomalous values for titanium and zinc elements (ppm).

\begin{tabular}{cccc}
\hline Background & Anomaly 1 & Anomaly 2 & Elements \\
\hline 5000 & 7800 & Upper 7800 & $\mathrm{Ti}$ \\
100 & 120 & Upper 120 & $\mathrm{Zn}$ \\
\hline
\end{tabular}

\subsubsection{Linear Discriminant Analysis (LDA)}

The LDA method was applied to separate the domains of $\mathrm{Ti}$ and $\mathrm{Zn}$ using the community separation results.

Community Separation Based on Ti Element Classifications

Three communities were separated for the Ti element (Figure 13); the communities and their element names are shown in Figure 14. The validity of this separation is provided in Table 7.

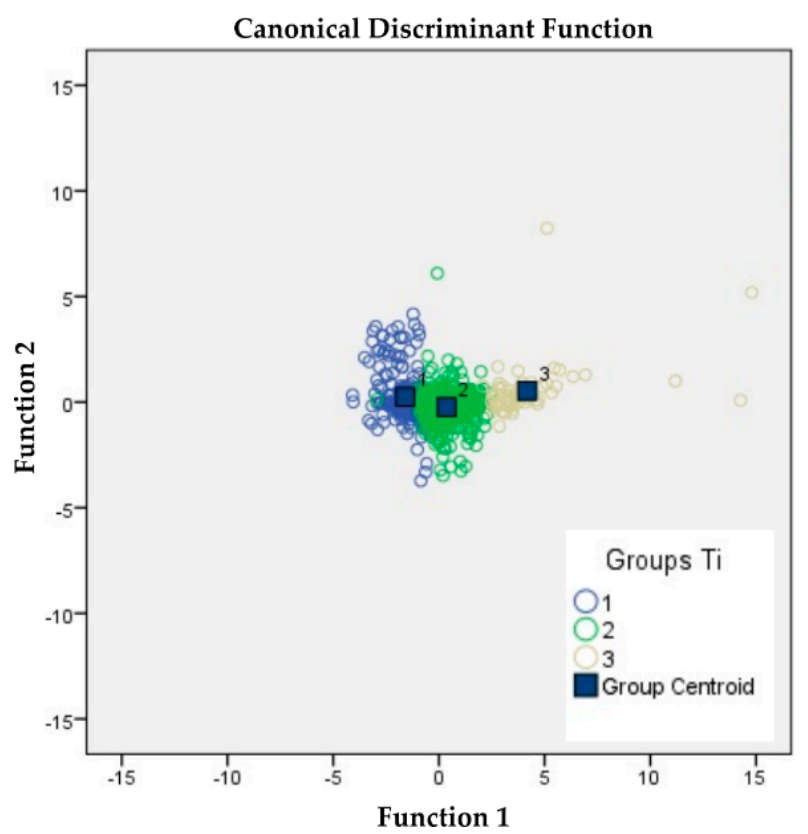

Figure 13. Separated communities of titanium element using LDA method. 


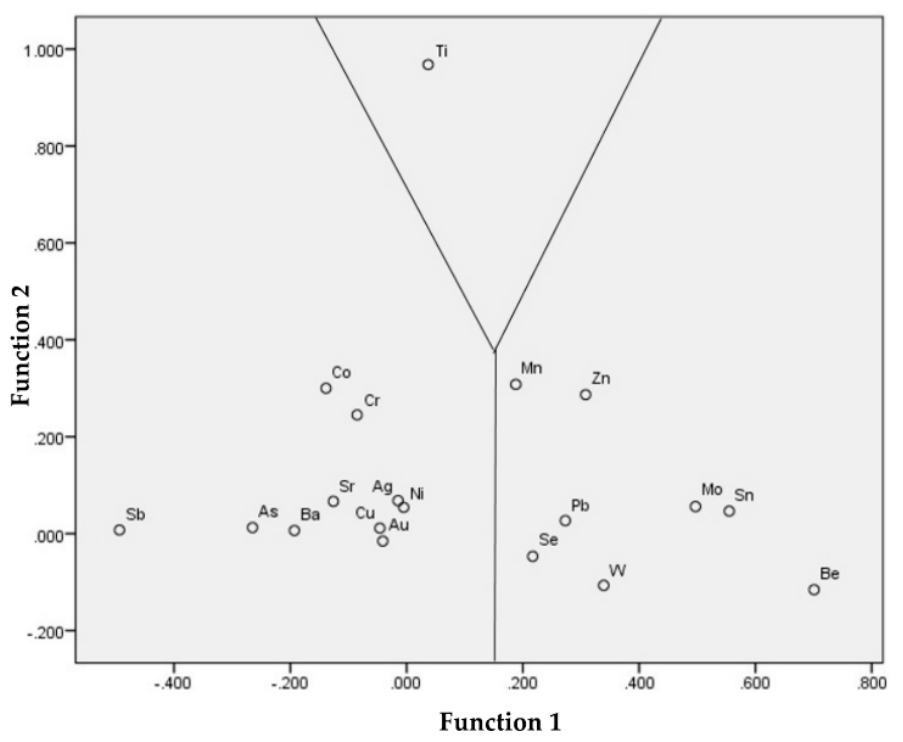

Figure 14. Separated communities of titanium element with name of members.

Table 7. LDA titanium communities cross validation.

\begin{tabular}{|c|c|c|c|c|c|c|}
\hline \multirow{2}{*}{\multicolumn{2}{|c|}{ Titanium Groups }} & & \multicolumn{3}{|c|}{ Predicted Group Membership } & \multirow{2}{*}{ Total } \\
\hline & & & First & Second & Third & \\
\hline \multirow{6}{*}{ CrossValidation } & \multirow{3}{*}{ Count } & First & 237 & 14 & 0 & 251 \\
\hline & & Second & 33 & 369 & 1 & 403 \\
\hline & & Third & 0 & 1 & 59 & 60 \\
\hline & \multirow{3}{*}{ Percentage } & First & 94.4 & 5.6 & 0 & 100 \\
\hline & & Second & 8.2 & 91.6 & 0.2 & 100 \\
\hline & & Third & 0 & 1.7 & 98.3 & 100 \\
\hline
\end{tabular}

Community Separation Based on Zn Element Classification

Three communities were separated for the Zn element (Figure 15); Figure 16 shows them with their element names in Figure 16. The validity of this separation is provided in Table 8.

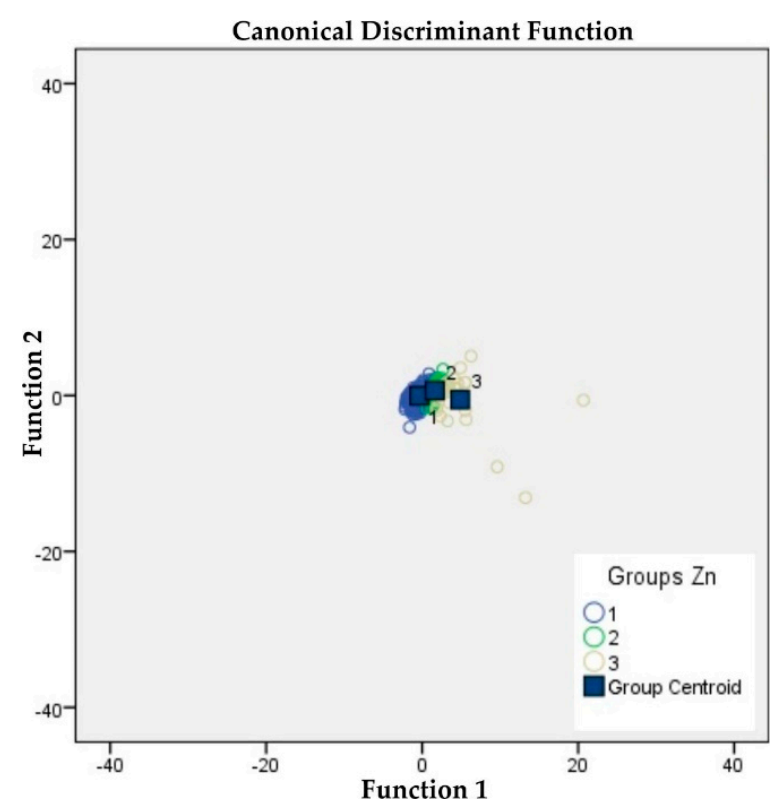

Figure 15. Separated communities of zinc element using LDA method. 


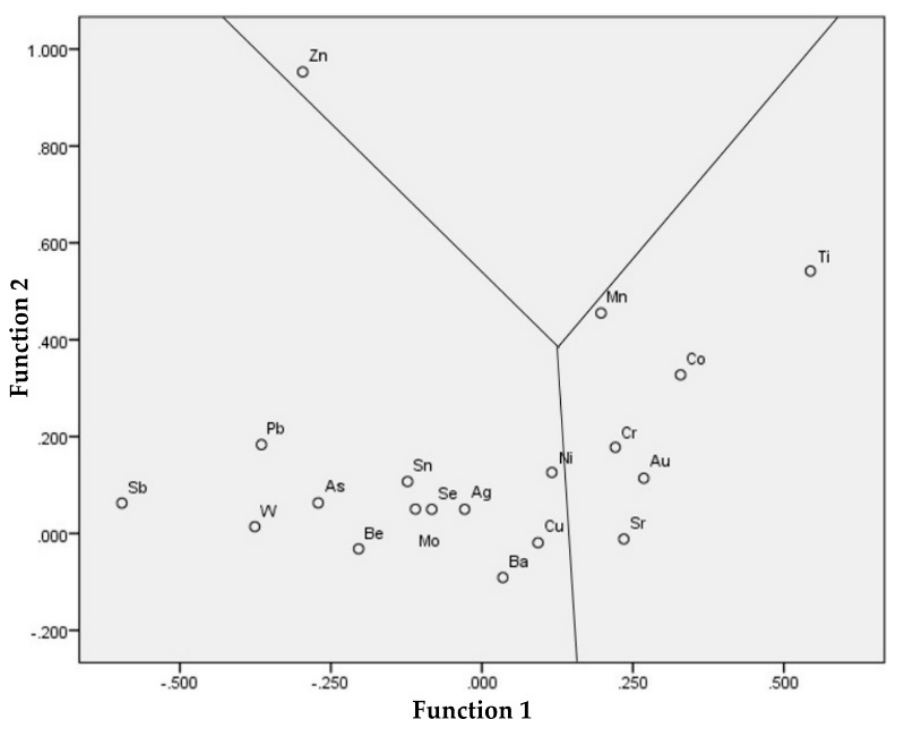

Figure 16. Separated communities of zinc element with name of members.

Table 8. LDA zinc communities cross validation.

\begin{tabular}{|c|c|c|c|c|c|c|}
\hline & \multirow{2}{*}{ Zinc Groups } & & \multicolumn{3}{|c|}{ Predicted Group Membership } & \multirow{2}{*}{ Tota } \\
\hline & & & First & Second & Third & \\
\hline \multirow{6}{*}{$\begin{array}{c}\text { Cross } \\
\text { Validation }\end{array}$} & \multirow{3}{*}{ Count } & First & 574 & 53 & 0 & 627 \\
\hline & & Second & 3 & 57 & 0 & 60 \\
\hline & & Third & 0 & 1 & 26 & 27 \\
\hline & \multirow{3}{*}{ Percentage } & First & 91.5 & 8.5 & 0 & 100 \\
\hline & & Second & 5 & 95 & 0 & 100 \\
\hline & & Third & 0 & 3.7 & 96.3 & 100 \\
\hline
\end{tabular}

The results listed in Table 8 indicate that the separation was performed with a high degree of accuracy. For example, $91.5 \%$ of samples are in the first group while only $8.5 \%$ are in the second group; the third group contains no data. This categorization can be considered for its general accuracy with respect to the high accuracy obtained in groups 1 and 2 and can be used for clustering.

\subsubsection{Anomaly Maps}

Anomalous samples obtained from the results were placed on the regional topographic map (Figures 17-19). 


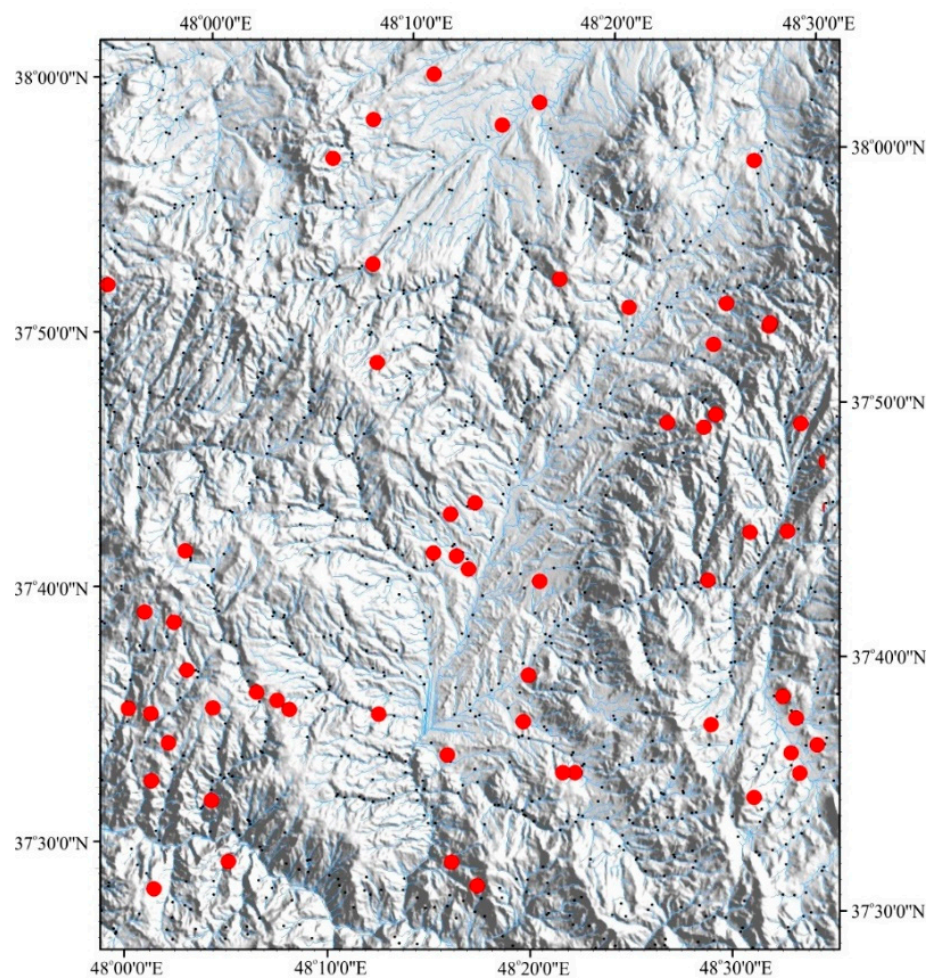

Figure 17. Map showing the distribution of Ti anomalous stream sediment samples.

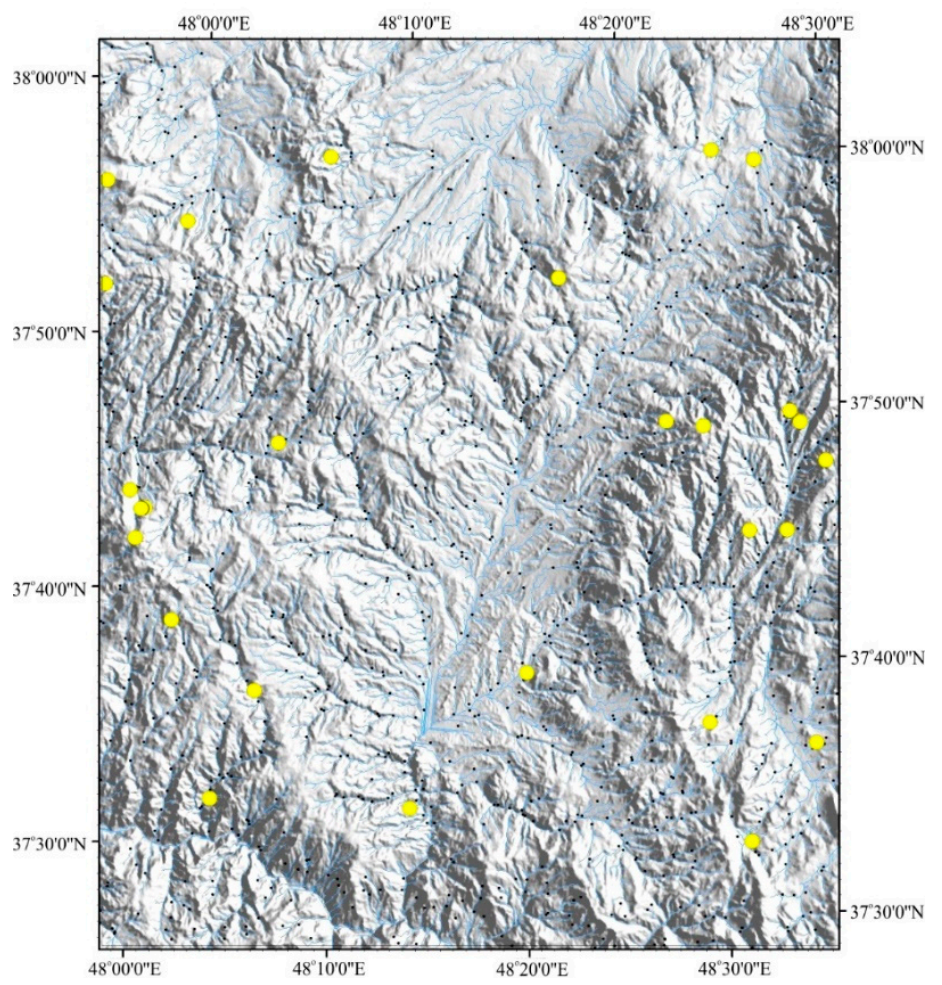

Figure 18. Anomalous samples of zinc element. 


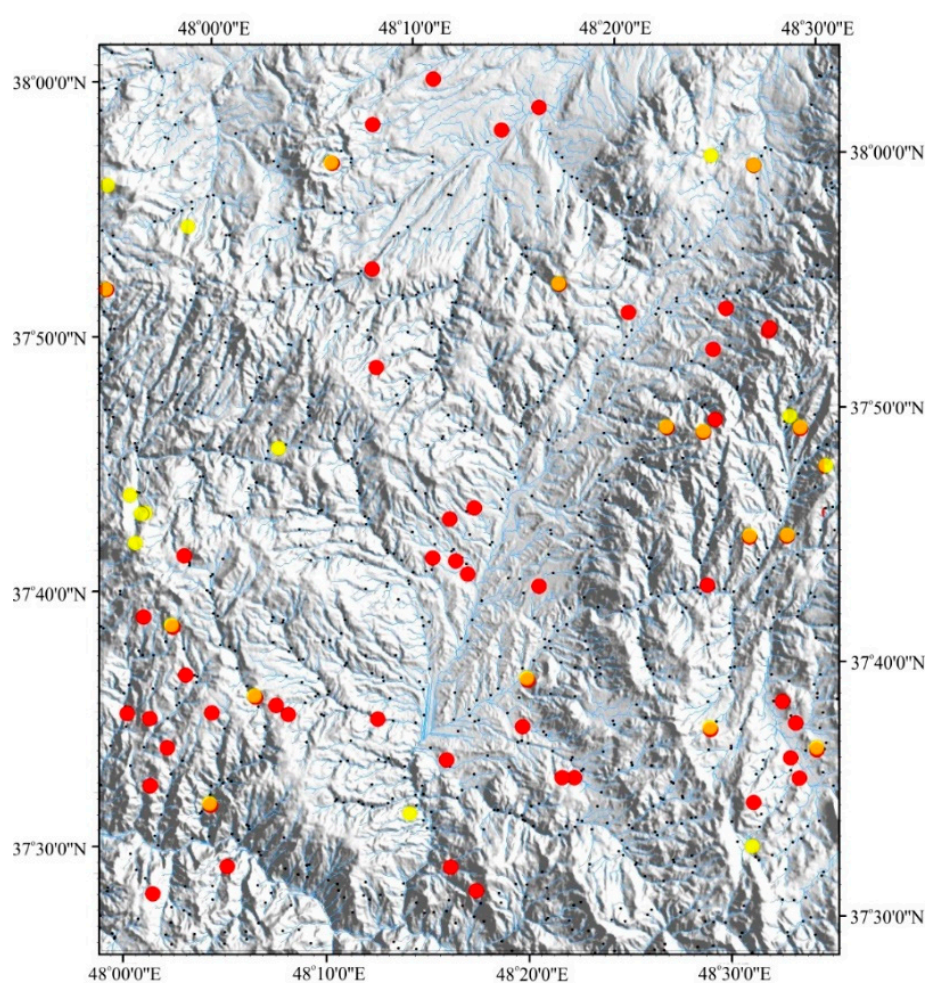

Figure 19. Display zinc (yellow) and titanium (red) anomal points together.

The results of statistical and geostatistical investigations were then used to identify the main anomalies for the Ti and Zn elements (Figures 20 and 21, respectively), and the identified Ti and Zn anomalies were plotted on the regional lithology map (Figures 22 and 23, respectively).

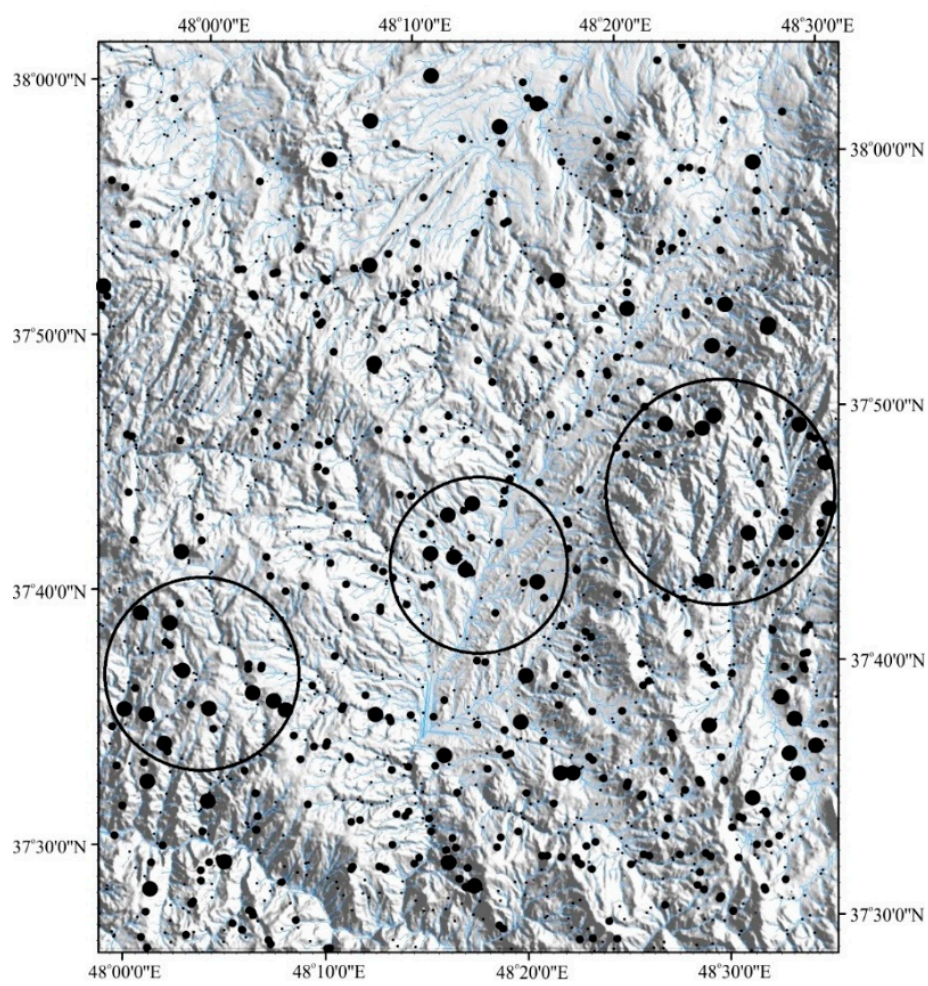

Figure 20. Small to large titanium concentrations in the streams and determined anomalous areas. 


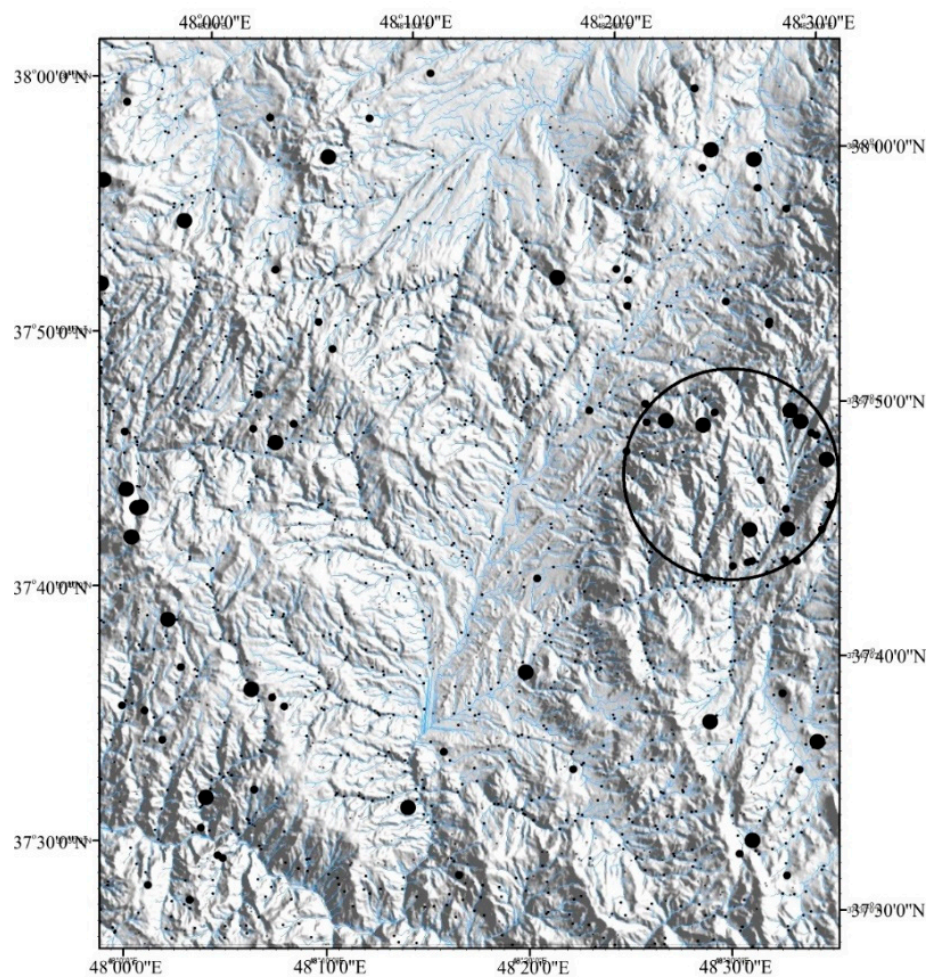

Figure 21. Small to large zinc concentrations in the streams and determined anomalous areas.

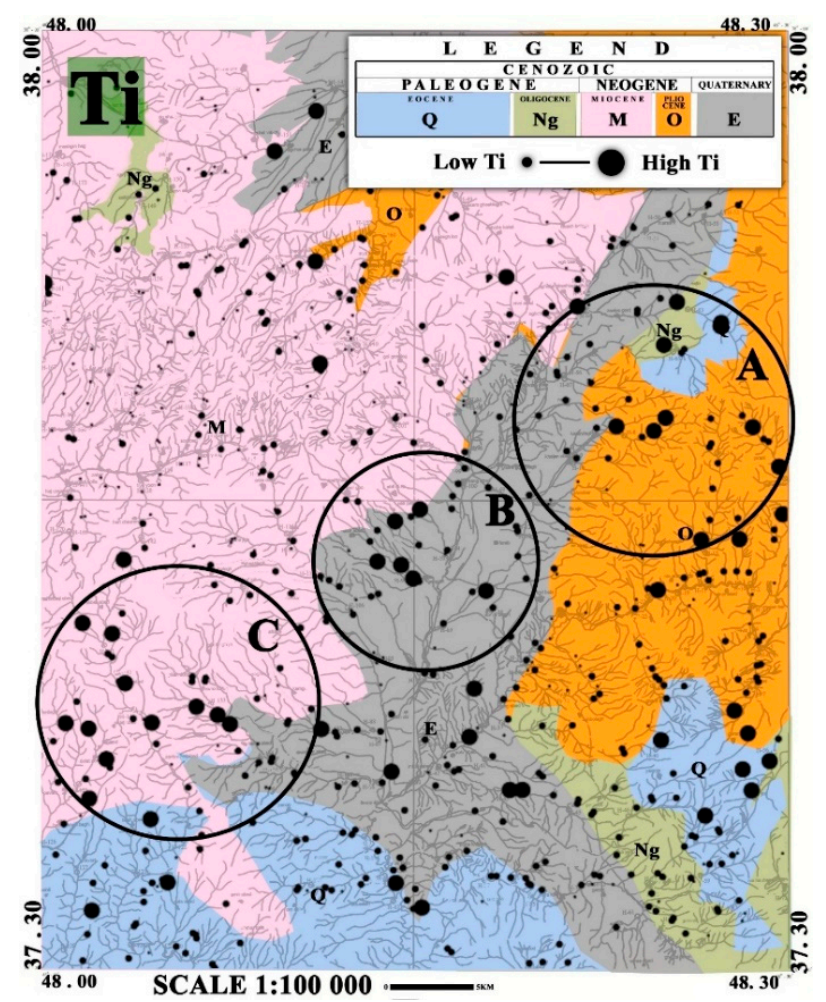

Figure 22. Small to large titanium concentrations on the lithology map and determined anomalous areas. 


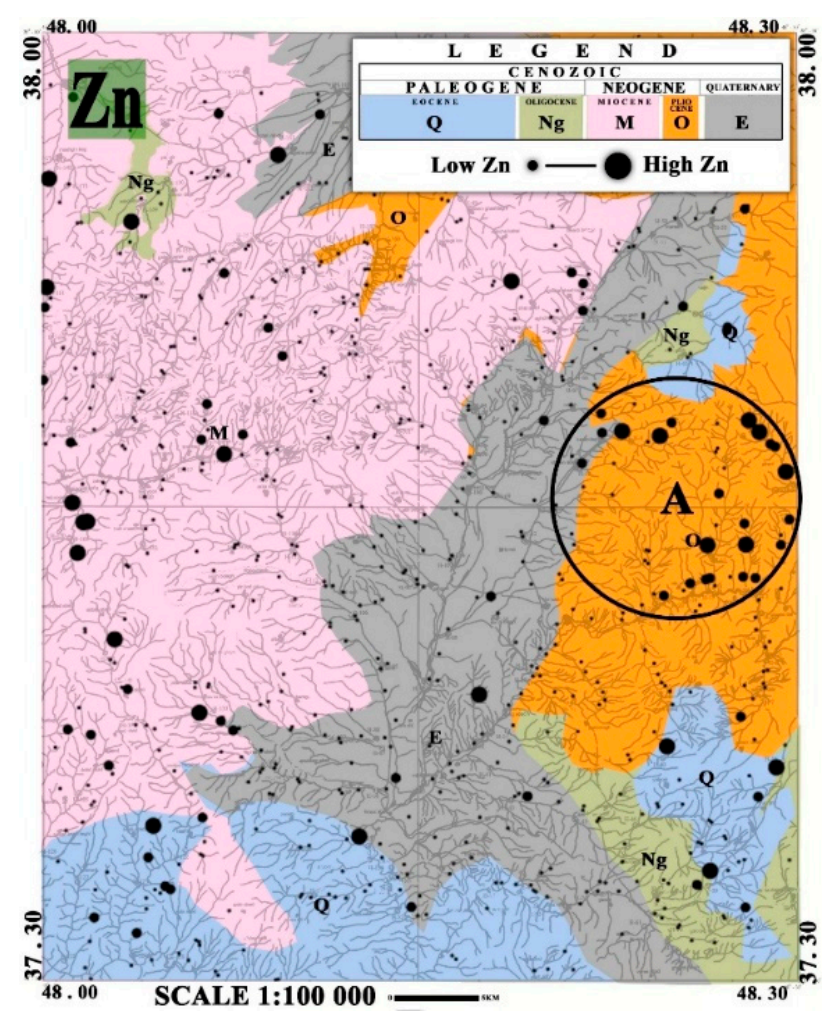

Figure 23. Small to large zinc concentrations on the lithology map and determined anomalous areas.

\subsection{Exploratory Remote Sensing}

\subsubsection{Band Math and Band Ratios}

Operational land imager (OLI) data were used to identify hydrothermal alterations in the region. To map the lithology, band ratios of 6/7,6/4, and 4/2 were assigned to the red, green, and blue (RGB) colors, respectively, as false color composite (FCC) ratios (Figure 24).

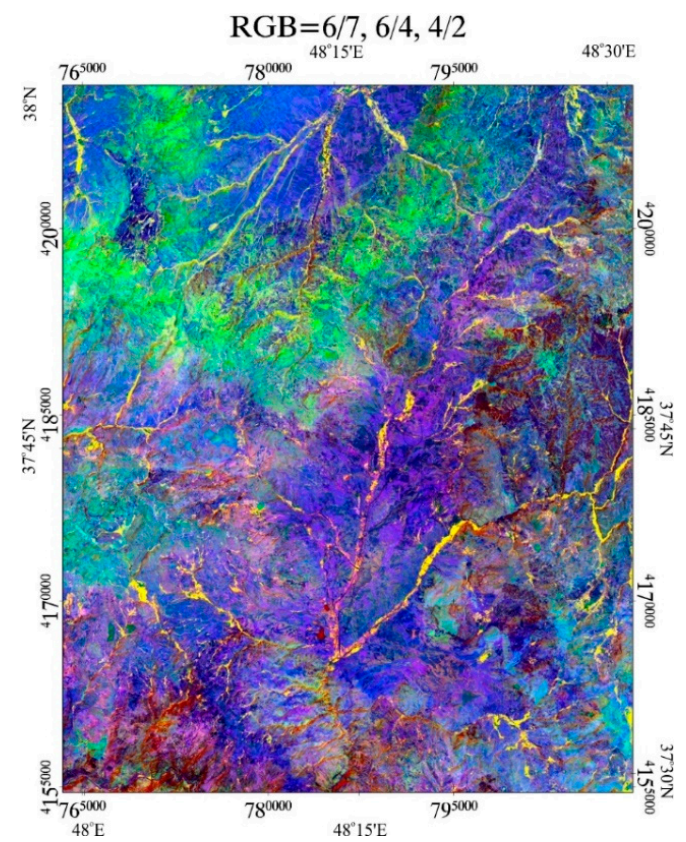

Figure 24. Red, green, and blue colors $(R G B)=6 / 7,6 / 4,4 / 2$ illuminates altered rocks as blue in image, yellow color lines are considered as vegetation. 
The results for RGB values of 7, 5, and 3 are presented in Figure 24. In addition to the geological map of Kivi in Figure 25, in which the dark violet colors represent basalt, andesite, and thick bedded volcanic conglomerate rock units, this image robustly separates the major lithological units within the region.

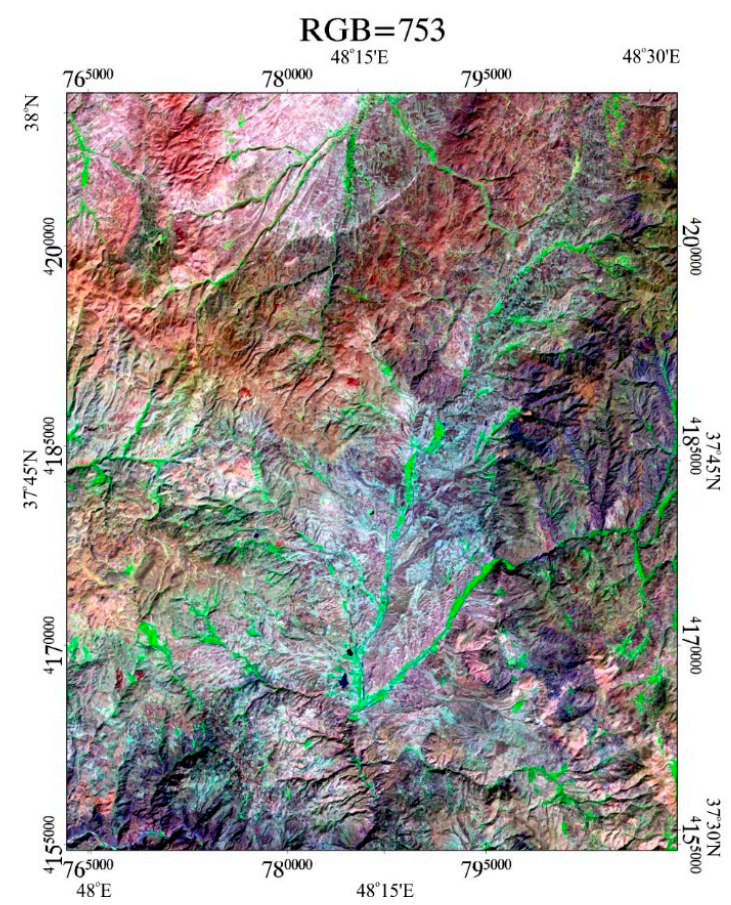

Figure 25. $\mathrm{RGB}=7,5,3$ as derived from Operational land imager (OLI) data delineates altered rocks as bright white color; dark violet represents basalt, andesite, and thick bedded volcanic conglomerate rock units.

\subsubsection{Principal Components Analysis (PCA)}

Figure 26 shows the first three general principal components (PCs) in RGB false colour format. The image contains nearly all spectral information gathered in nine OLI bands, and the accumulation of spectral information helps to represent the discriminated rock unites in different colors.

DSPCA was used to map aluminum (AL)-hydroxy $(\mathrm{OH})$-bearing altered rocks. For this purpose, bands 2, 5, 6, and 7 were selected; the statistical results are listed in Table 9.

Table 9. PCA eigenvector matrix for Kivi area.

\begin{tabular}{ccccc}
\hline $\begin{array}{c}\text { Principal } \\
\text { Components }\end{array}$ & Second Band & Fifth Band & Sixth Band & Seventh Band \\
\hline First PC & +0.14 & +0.39 & +0.71 & +0.54 \\
Second PC & +0.28 & +0.78 & -0.32 & -0.36 \\
Third PC & +0.79 & -0.19 & -0.37 & +0.29 \\
Forth PC & -0.37 & +0.24 & -0.66 & +0.68 \\
\hline
\end{tabular}

Considering the PC loadings for seventh (+0.68) and sixth bands $(-0.66), \mathrm{OH}$-bearing altered minerals were provided in PC 4 to enhance the altered zones (Table 9). Figure 27 shows the altered areas from PC 4 mapped in red. 


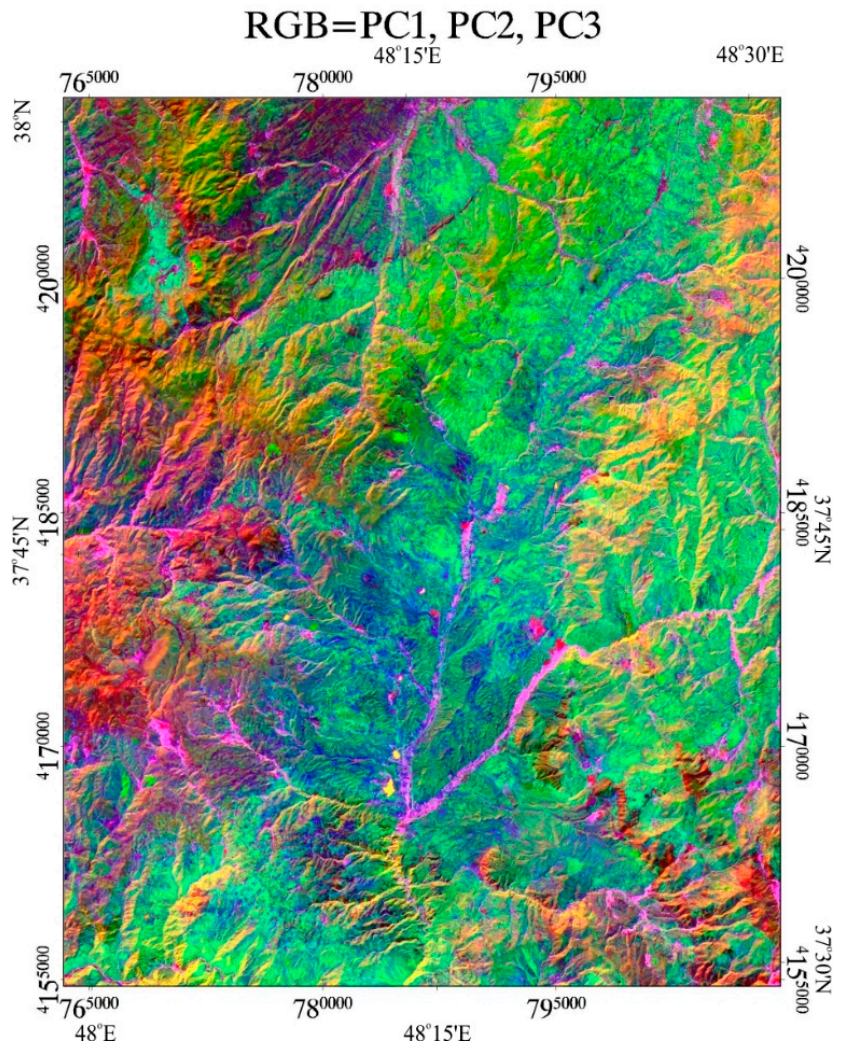

Figure 26. $\mathrm{RGB}=\mathrm{PC} 1, \mathrm{PC}$, and $\mathrm{PC} 3$, showing different rock classes in a variant range.

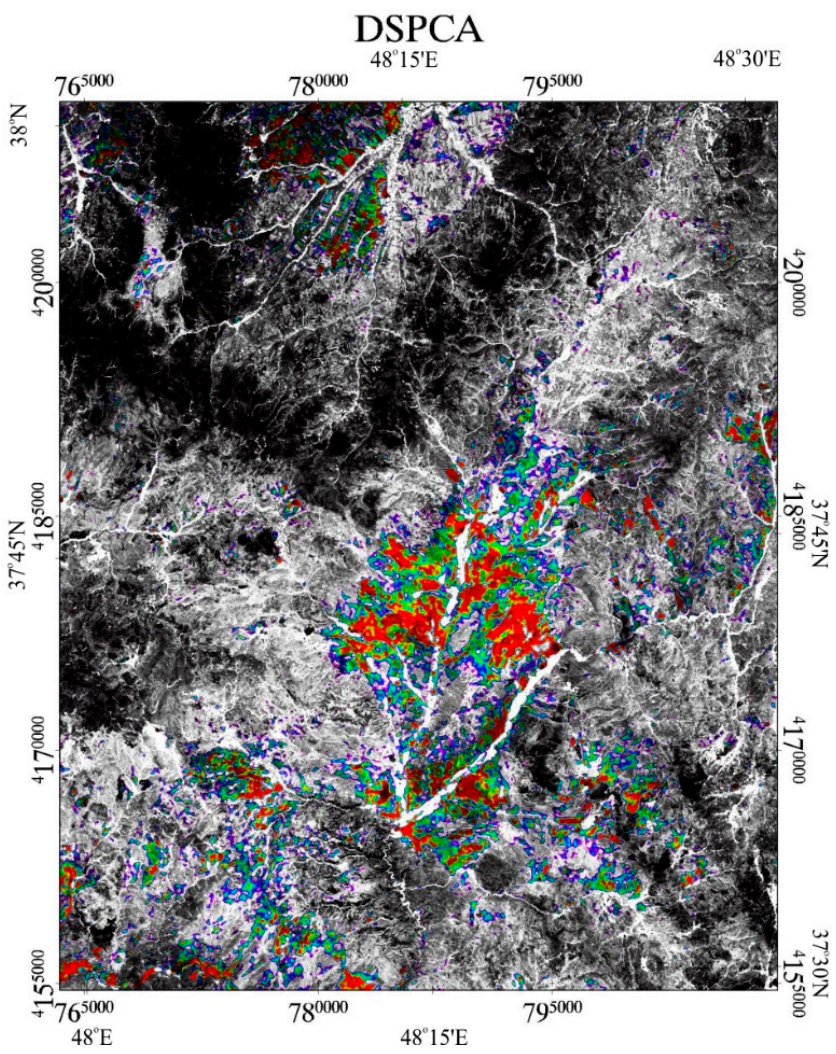

Figure 27. Alteration density map driven from band ratios and developed selective PCA (DSPCA) for detecting clay minerals in study area. Red color stands for extensive clay mineral overlay. 


\section{Conclusions}

Based on the results of this study on geostatistical data and remote sensing, we present the following conclusions.

- Clearly, the Kivi region is a high-potential area for metallogenic exploration.

- $\quad T i$ and Zn were identified as anomalous elements based on single-variable studies and comparison with the background threshold limits of stream sediment. According to the geological information, there are other metal elements in the region, including $\mathrm{Cu}$ in basalt; however, their presence in the stream sediment samples did not reach the anomalous threshold limit.

- An investigation of the relationship between the two identified elements using hierarchical and correlation analyses revealed a strong positive correlation between the two elements. The hierarchical clustering also confirmed that the $\mathrm{Ti}$ and $\mathrm{Zn}$ elements are the primary anomalous elements in the region.

- Different communities of Ti and Zn elements were separated using a probability diagram and the results were subjected to LDA analysis to obtain separate groupings between Ti and $\mathrm{Zn}$ and their associated elements. The results were estimated through cross-validation with more than $90 \%$ validity.

- PCA results indicated that the first and second components represent the lithology and mineralization of the region, respectively.

- Based on geological mapping and RS investigation, the trend of identified anomalies was found to follow volcanic and plutonic calc-alkaline rocks belonging to the Eocene epoch, including basalt, andesite, and thick bedded volcanic conglomerate rock units in addition to the alluvial deposits resulting from their erosion and weathering over time.

- Minerals of economic interest containing Ti metal include ilmenite and rutile. Given the presence of these minerals in the area, there is a possibility of ore deposits. Other Ti anomalies with no economic value can be derived from pyroxenes and biotite. In the future, heavy mineral studies should be conducted in regions identified as anomalies to identify the types of minerals containing Ti.

Author Contributions: A.S. conceived and designed the study and wrote the initial draft of the manuscript. A.S. and M.Z. collected the samples and conducted sample preparation for analytical work. A.S., M.Z., and A.H. analyzed the data, and conducted processing graphic and analytical work. T.T. revised and corrected the final version. All authors have read and agreed to the published version of the manuscript.

Funding: This research received no external funding.

Acknowledgments: Laboratory investigations were carried out at Tomsk Polytechnic University within the framework of a Competitiveness Enhancement Program Grant. We thank the editor and three anonymous reviewers for their constructive criticisms and revisions, which led to improvement of the manuscript.

Conflicts of Interest: The authors declare no conflict of interest.

\section{References}

1. Zhang, B.; Wang, X.; Ye, R.; Zhou, J.; Liu, H.; Liu, N.; Han, Z.; Lin, X.; Wang, Z. Geochemical exploration for concealed deposits at the periphery of the Zijinshan copper-gold mine, southeastern China. J. Geochem. Explor. 2015, 157, 184-193. [CrossRef]

2. Gandhi, S.M.; Sarkar, B.C.; Gandhi, S.M.; Sarkar, B.C. Geochemical exploration. In Essentials of Mineral Exploration and Evaluation; Elsevier: Amsterdam, The Netherlands, 2016; pp. 125-158.

3. Zuo, R.; Carranza, E.J.M.; Wang, J. Spatial analysis and visualization of exploration geochemical data. Earth Sci. Rev. 2016, 158, 9-18. [CrossRef]

4. Cherkasova, T.; Chernishov, A.; Goltsova, Y.; Timkin, T.; Abramova, R. Petrogenetic characteristics of mafic-ultramafic massifs in Nizhne-Derbinsk complex (East Sayan Mountains). IOP Conf. Ser. Earth Environ. Sci. 2015, 27, 012002. [CrossRef] 
5. Yousefi, M. Recognition of an enhanced multi-element geochemical signature of porphyry copper deposits for vectoring into mineralized zones and delimiting exploration targets in Jiroft area, SE Iran. Ore Geol. Rev. 2017, 83, 200-214. [CrossRef]

6. Ziaii, M.; Safari, S.; Timkin, T.V.; Voroshilov, V.; Yakich, T. Identification of geochemical anomalies of the porphyry- $\mathrm{Cu}$ deposits using concentration gradient modelling: A case study, Jebal-Barez area, Iran. J. Geochem. Explor. 2019, 199, 16-30. [CrossRef]

7. Saadati, H.; Afzal, P.; Torshizian, H.; Solgi, A. Geochemical exploration for lithium in NE Iran using the geochemical mapping prospectivity index, staged factor analysis, and a fractal model. Geochem. Explor. Environ. Anal. 2020. [CrossRef]

8. Timkin, T.V.; Voroshilov, V.; Askanakova, O.; Cherkasova, T.; Chernyshov, A.; Korotchenko, T. Estimating gold-ore mineralization potential within Topolninsk ore field (Gorny Altai). IOP Conf. Series: Earth Environ. Sci. 2015, 27, 12010. [CrossRef]

9. Shirazy, A.; Shirazi, A.; Ferdossi, M.H.; Ziaii, M.; Adel, S.; Aref, S.; Mohammad, H.F.; Mansour, Z. Geochemical and geostatistical studies for estimating gold grade in tarq prospect area by k-means clustering method. Open J. Geol. 2019, 9, 306-326. [CrossRef]

10. Shirazi, A.; Shirazy, A.; Saki, S.; Hezarkhani, A. Introducing a software for innovative neuro-fuzzy clustering method named NFCMR. Glob. J. Comput. Sci. Theory Res. 2018, 8, 62-69. [CrossRef]

11. Khakmardan, S.; Shirazi, A.; Shirazy, A.; Hosseingholi, H. Copper oxide ore leaching ability and cementation behavior, mesgaran deposit in Iran. Open J. Geol. 2018, 8, 841-858. [CrossRef]

12. Cheng, Q.; Bonham-Carter, G.; Wang, W.; Zhang, S.; Li, W.; Qinglin, X. A spatially weighted principal component analysis for multi-element geochemical data for mapping locations of felsic intrusions in the Gejiu mineral district of Yunnan, China. Comput. Geosci. 2011, 37, 662-669. [CrossRef]

13. Templ, M.; Filzmoser, P.; Reimann, C. Cluster analysis applied to regional geochemical data: Problems and possibilities. Appl. Geochem. 2008, 23, 2198-2213. [CrossRef]

14. Liu, Y.; Zhou, K.; Carranza, E.J.M. Compositional balance analysis for geochemical pattern recognition and anomaly mapping in the western Junggar region, China. Geochem. Explor. Environ. Anal. 2018, 18, 263-276. [CrossRef]

15. Roshani, P.; Mokhtari, A.R.; Tabatabaei, S.H. Objective based geochemical anomaly detection-Application of discriminant function analysis in anomaly delineation in the Kuh Panj porphyry Cu mineralization (Iran). J. Geochem. Explor. 2013, 130, 65-73. [CrossRef]

16. Grunsky, E.C.; de Caritat, P. State-of-the-art analysis of geochemical data for mineral exploration. Geochem. Explor. Environ. Anal. 2020, 20, 217-232. [CrossRef]

17. Ni, P.; Li, S.-N.; Bao, T.; Zheng, W.-Y.; Wang, G.-G.; Xiang, H.-L.; Chi, Z.; Pan, J.-Y.; Huang, B.; Ding, J.-Y.; et al. Mapping of fluid, alteration and soil geochemical anomaly as a guide to regional mineral exploration for the Dehua gold orefield of Fujian Province, SE China. Geochem. Explor. Environ. Anal. 2018, 19, 74-90. [CrossRef]

18. Hassanipak, A.A.; Sharafeddin, M. Exploration Data Analysis; Tehran University Press: Tehran, Iran, 2005; Volume 1. (In Persian)

19. Grubbs, F.E. Procedures for detecting outlying observations in samples. Technometrics 1969, 11, 1-21. [CrossRef]

20. Madala, G.S. Introduction to Econometrics, 2nd ed.; Maxmillan Publishing Company: New York, NY, USA, 1992.

21. Kalisch, M.; Michalak, M.; Sikora, M.; Wróbel, Ł.; Przystalka, P. Influence of outliers introduction on predictive models quality. In Proceedings of the 12th International Conference, BDAS 2016, Ustron, Poland, 31 May-3 June 2016; Volume 613, pp. 79-93.

22. Shirazi, A.; Shirazy, A.; Saki, S.; Hezarkhani, A. Geostatistics studies and geochemical modeling based on core data, sheytoor iron deposit, Iran. J. Geol. Resour. Eng. 2018, 6, 124-133. [CrossRef]

23. Hassani Pak, A. Geostatistics; University of Tehran: Tehran, Iran, 1998. (In Persian)

24. Yousefi, M. General and Detailed Exploration of Iron Ore Anomalies of Iran's Central Plateau, 5a Anomlay (Sheytoor-Gazestan); Madankav Engineering Co.: Tehran, Iran, 2016.

25. Chatfield, C.; Collins, A.J.; Chatfield, C. Introduction to Multivariate Analysis; Springer: New York, NY, USA, 2018. [CrossRef]

26. Mertler, C.A.; Reinhart, R.V. Advanced and Multivariate Statistical Methods: Practical Application and Interpretation, 5th ed.; Routledge: London, UK, 2016; p. 374. 
27. Rollinson, H.R. Using Geochemical Data: Evaluation, Presentation, Interpretation; Taylor and Francis: Oxfordshire, UK, 2014.

28. Alahgholi, S.; Shirazy, A.; Shirazi, A. Geostatistical studies and anomalous elements detection, Bardaskan area, Iran. Open J. Geol. 2018, 8, 697-710. [CrossRef]

29. Rokach, L.; Maimon, O. Clustering methods. In Data Mining and Knowledge Discovery Handbook; Springer: New York, NY, USA, 2005; pp. 321-352.

30. Manuel, R.; Brito, G.; Chichorro, M.; Rosa, C. Remote sensing for mineral exploration in central Portugal. Minerals 2017, 7, 184. [CrossRef]

31. Wang, G.; Du, W.; Carranza, E.J.M. Remote sensing and GIS prospectivity mapping for magmatic-hydrothermal base- and precious-metal deposits in the Honghai district, China. J. Afr. Earth Sci. 2017, 128, 97-115. [CrossRef]

32. Gómez-Palacios, D.; Torres, M.A.; Reinoso, E. Flood mapping through principal component analysis of multitemporal satellite imagery considering the alteration of water spectral properties due to turbidity conditions. Geomat. Nat. Hazards Risk 2016, 8, 607-623. [CrossRef]

33. Soe, M.; Kyaw, T.A.; Takashima, I. Application of Remote Sensing Techniques on Iron Oxide Detection from ASTER and Landsat Images of Tanintharyi Coastal Area, Myanmar. Available online: https://citeseerx.ist. psu.edu/viewdoc/download?doi=10.1.1.598.998\&rep=rep1\&type=pdf (accessed on 25 August 2020).

34. Chien, N.P.; Lautz, L.K. Discriminant analysis as a decision-making tool for geochemically fingerprinting sources of groundwater salinity. Sci. Total Environ. 2018, 618, 379-387. [CrossRef] [PubMed]

35. Yakubu, I.; Dinye, R.; Buor, D.; Iddrisu, W.A.; Yakubu, I.; Dinye, R.; Buor, D.; Iddrisu, W.A. Discriminant analysis of demand-side roadblocks to financial inclusion in Northern Ghana. J. Math. Financ. 2017, 7, 718-733. [CrossRef]

36. Friedman, J.H. Regularized discriminant analysis. J. Am. Stat. Assoc. 1989, 84, 165-175. [CrossRef]

37. Klecka, W. Discriminant analysis. Adv. Neural Inform. Proc. Syst. 1980, 17, 1569-1576. [CrossRef]

38. Shirazi, A.; Shirazy, A.; Karami, J. Remote sensing to identify copper alterations and promising regions, Sarbishe, South Khorasan, Iran. Int. J. Geol. Earth Sci. 2018, 4, 36-52.

39. Adiri, Z.; Lhissou, R.; El Harti, A.; Jellouli, A.; Chakouri, M. Recent advances in the use of public domain satellite imagery for mineral exploration: A review of Landsat- 8 and Sentinel-2 applications. Ore Geol. Rev. 2020, 117, 103332. [CrossRef]

40. Abrams, M. The advanced spaceborne thermal emission and reflection radiometer (ASTER): Data products for the high spatial resolution imager on NASA's Terra platform. Int. J. Remote. Sens. 2000, 21, 847-859. [CrossRef]

41. Irons, J.R.; Dwyer, J.; Barsi, J.A. The next Landsat satellite: The Landsat data continuity mission. Remote. Sens. Environ. 2012, 122, 11-21. [CrossRef]

42. Markham, B.; Storey, J.; Williams, D.; Irons, J. Landsat sensor performance: History and current status. IEEE Trans. Geosci. Remote. Sens. 2004, 42, 2691-2694. [CrossRef]

43. Morfitt, R.; Barsi, J.A.; Levy, R.; Markham, B.; Micijevic, E.; Ong, L.; Scaramuzza, P.; Vanderwerff, K. Landsat-8 operational land imager (OLI) radiometric performance on-orbit. Remote Sens. 2015, 7, 2208-2237. [CrossRef]

44. Pour, A.B.; Hashim, M. Hydrothermal alteration mapping from Landsat-8 data, Sar Cheshmeh copper mining district, south-eastern Islamic Republic of Iran. J. Taibah Univ. Sci. 2015, 9, 155-166. [CrossRef]

45. Safari, M.; Maghsoudi, A.; Pour, A.B. Application of Landsat- 8 and ASTER satellite remote sensing data for porphyry copper exploration: A case study from Shahr-e-Babak, Kerman, south of Iran. Geocarto Int. 2017, 33, 1186-1201. [CrossRef]

46. Aspinall, R.J.; Marcus, W.; Boardman, J.W. Considerations in collecting, processing, and analysing high spatial resolution hyperspectral data for environmental investigations. J. Geogr. Syst. 2002, 4, 15-29. [CrossRef]

47. Shirazi, A.; Hezarkhani, A.; Shirazy, A. Remote sensing studies for mapping of iron oxide regions, South of Kerman, IRAN. Int. J. Sci. Eng. Appl. 2018, 7, 45-51. [CrossRef]

(C) 2020 by the authors. Licensee MDPI, Basel, Switzerland. This article is an open access article distributed under the terms and conditions of the Creative Commons Attribution (CC BY) license (http://creativecommons.org/licenses/by/4.0/). 